US Army Corps

of Engineers

Engineer Research and

Development Center

Water Operations Technical Support Program

\title{
Diffusive and Kinetic Fluxes of Phosphorus from Sediments in Relation to Phosphorus Dynamics in Lake Pepin, Upper Mississippi River
}

by William F. James, John W. Barko, Harry L. Eakin

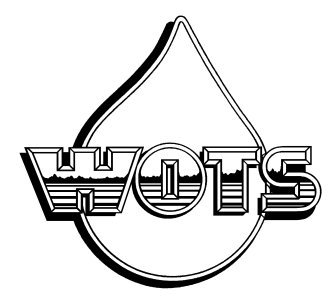


The contents of this report are not to be used for advertising, publication, or promotional purposes. Citation of trade names does not constitute an official endorsement or approval of the use of such commercial products.

The findings of this report are not to be construed as an official Department of the Army position, unless so designated by other authorized documents. 


\section{Diffusive and Kinetic Fluxes of Phosphorus from Sediments in Relation to Phosphorus Dynamics in Lake Pepin, Upper Mississippi River}

by William F. James, John W. Barko, Harry L. Eakin

U.S. Army Engineer Research and Development Center Waterways Experiment Station 3909 Halls Ferry Road

Vicksburg, MS 39180-6199

Final report

Approved for public release; distribution is unlimited 


\section{U.S. Army Engineer Research and Development Center Cataloging-in-Publication Data}

James, William F.

Diffusive and kinetic fluxes of phosphorus from sediments in relation to phosphorus dynamics in Lake Pepin, upper Mississippi River / by William F. James, John W. Barko, Harry L. Eakin ; prepared for U.S. Army Corps of Engineers.

44 p. : ill. ; 28 cm. -- (Miscellaneous paper ; W-99-1)

Includes bibliographic references.

1. Phosphorus. 2. Water quality -- Mississippi River. 3. Water -- Phophorus content. 4. Water quality -- Minnesota -- Pepin, Lake. I. Barko, John W. II. Eakin, Harry L. III. United States. Army. Corps of Engineers. IV. U.S. Amy Engineer Research and Development Center. V. Water Operations Technical Support Program (U.S.) VI. Title. VII. Miscellaneous paper (U.S. Army Engineer Research and Development Center) ; W-99-1.

TA7 W34m no.W-99-1 


\section{Contents}

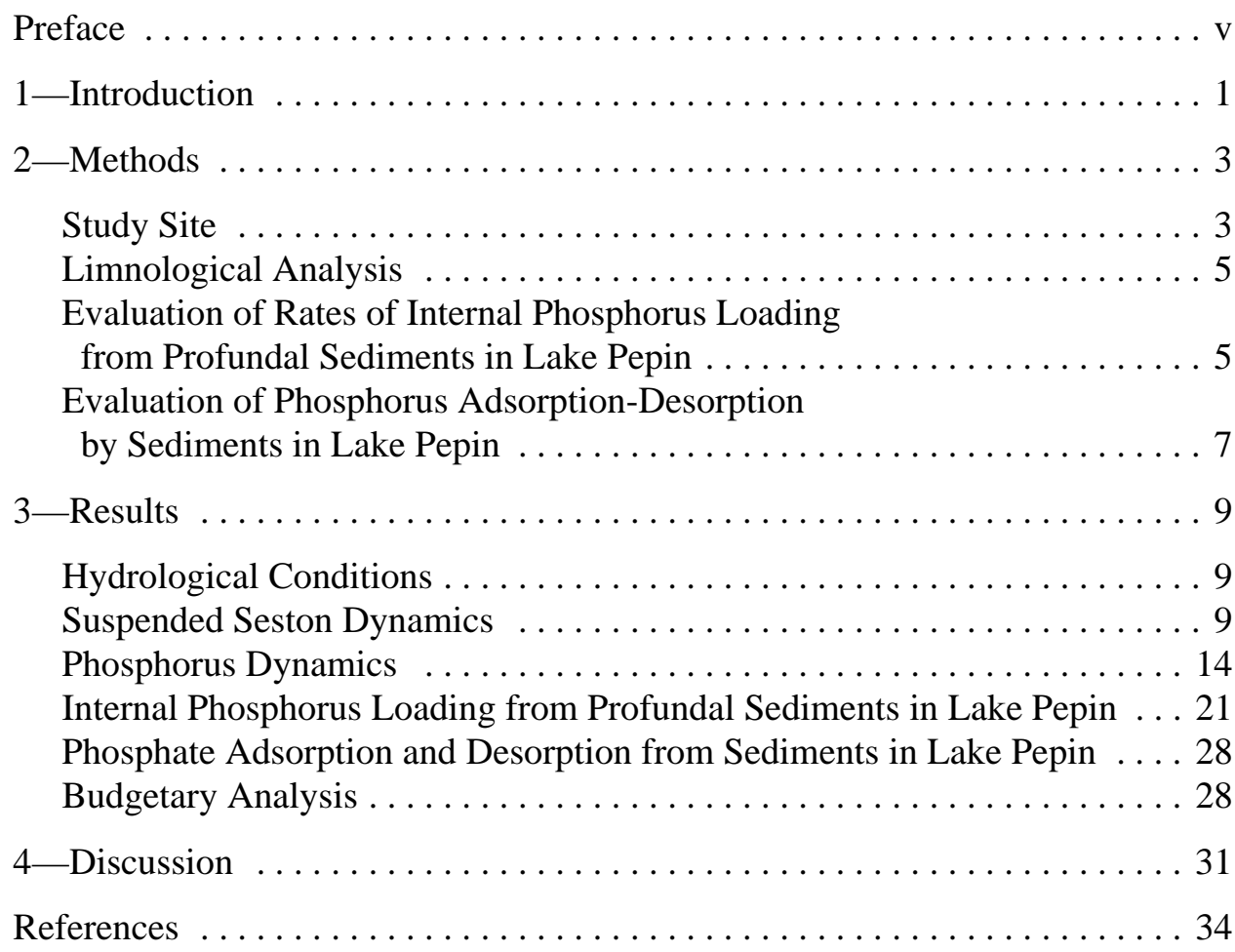

SF 298

\section{List of Figures}

Figure 1. Locations of sampling and gauging stations

in Upper Mississippi River system $\ldots \ldots \ldots \ldots \ldots \ldots \ldots 4$

Figure 2. Locations of water and sediment sampling stations

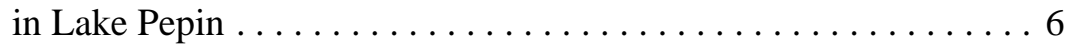

Figure 3. Relative contributions (percent) by various sources

to annual water income of Lake Pepin during years 1994-96 . . . 10 
Figure 4. Inflow, outflow, and residence time for Lake Pepin

during years $1994-96 \ldots \ldots \ldots \ldots \ldots \ldots \ldots \ldots \ldots \ldots$

Figure 5. Relative contributions (percent) by various sources to annual suspended seston load of Lake Pepin

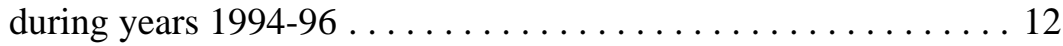

Figure 6. Seasonal variations in weighted suspended seston concentrations at UM787.0, UM784.0, UM781.0, UM778.0, UM775.0, UM771.0, and UM766.0 in Lake Pepin during years 1994-1996 . . . . . . . . . . . . . 15

Figure 7. Relative contributions (percent) by various sources to annual total phosphorus load of Lake Pepin

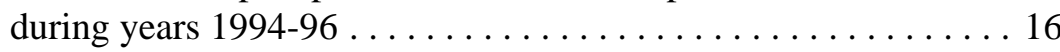

Figure 8. Relative contributions (percent) by various sources to annual soluble reactive phosphorus (SRP) load of Lake Pepin during years 1994-96 . . . . . . . . . . . . . 17

Figure 9. Seasonal variations in (a) SRP concentration and flow, (b) SRP loading and discharge, and (c) net SRP retention/ export for Lake Pepin during years 1994-96 . . . . . . . . . . . . 18

Figure 10. Seasonal variations in (a) total $\mathrm{P}$, (b) soluble reactive $\mathrm{P}$, and (c) SRP:TP in Lake Pepin during years 1994-96 at Stations UM787.0, UM 781.0, UM775.0, UM771.0,

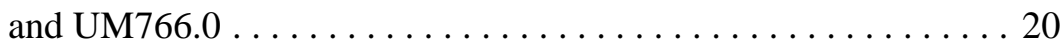

Figure 11. Longitudinal and vertical variations in SRP in Lake Pepin on (a) 05 July 1994 and (b) 10 September 1996 . . . . . . . . . 22

Figure 12. Surface contours of seasonal and longitudinal variations in SRP concentrations from River Mile (RM) 847 to 764 for the summers of $1994-96 \ldots \ldots \ldots \ldots \ldots \ldots \ldots$

Figure 13. Variations in laboratory-derived mean $( \pm 1$ S.E.) rates of phosphorus $(\mathrm{P})$ release from sediments under oxic and anoxic conditions as a function of temperature for sediment collected in Lake Pepin . . . . . . . . . . . 26

Figure 14. Seasonal variations in estimated whole-lake rate of phosphorus $(\mathrm{P})$ release from sediment in Lake Pepin

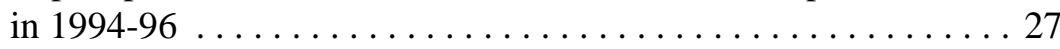

Figure 15. Adsorption or desorption (i.e., delta SRP) of P over a 24-hr period as a function of final SRP equilibrium concentration for surface sediments collected in Lake Pepin . . . . 29 


\section{Preface}

The work reported herein was conducted as part of the Water Operations Technical Support (WOTS) Program. The WOTS Program is sponsored by the Headquarters, U.S. Army Corps of Engineers (HQUSACE), and is assigned to the U.S. Army Engineer Research and Development Center (ERDC) under the purview of the Environmental Laboratory (EL). Funding was provided under Department of the Army Appropriation 96X3123, Operations and Maintenance. Dr. John W. Barko was Program Manager for the WOTS Program.

Mr. Robert C. Gunkel, Jr., was Assistant Manager for the WOTS Program. Program Monitors during this study were Mr. Frederick B. Juhle and Mr. Lewis Smith, HQUSACE.

This study was also conducted in response to a request from the Metropolitan Council (St. Paul, MN) to the U.S. Army Engineer District, St. Paul, for planning assistance under Section 22 of the Water Resources Development Act (Public Law 93-251). Additional funding was provided by the Metropolitan Council and the St. Paul District. Study coordinator for the Metropolitan Council was Mr. Kent Johnson. The Section 22 coordinator for the St. Paul District was Mr. Terry Engel.

This study was conducted and the report written by Mr. William F. James, Dr. John W. Barko, and Mr. Harry L. Eakin, Ecosystem Processes and Effects Division (EPED), EL, ERDC. We gratefully acknowledge the assistance of Ms. Cathy Larson and Messrs. Kent Johnson, Michael Meyer, and Scott Schellhaus of the Metropolitan Council for sampling tributary inflows and compiling flow information; Mr. Robert Burdis of the Minnesota Department of Natural Resources (Lake City, MN) for providing assistance in spatial water sampling on Lake Pepin; Mr. James Rogala of the U.S. Geological Survey Upper Midwest Environmental Sciences Center, Onalaska, WI, for providing water volume data and a coordinate system for spatial sampling in Lake Pepin; Ms. Bonnie Montgomery of the St. Paul District for providing flow information for Lock and Dams 1 through 4 and pool elevation data for Lake Pepin; the U.S. Geological Survey of Minnesota and Wisconsin for providing flow information for various tributaries entering Lake Pepin; Mses. Susan Fox and Kimberly Deevers, AScI Corporation, for conducting sediment fractionations and sediment chemical analyses; and Ms. Michele Huppert and Mr. Dale Dressel, AScI Corporation, and Mses. Valerie Hurtgen, Sara Krause, Brenda 
Lamb, Suzanne Riddick, Amie Soderquist, and Holly Wallace and Mr. Eugene Isherwood of the Eau Galle Aquatic Ecology Laboratory, EL, Spring Valley, WI, for water and sediment sampling, chemical analysis, and the execution of studies on phosphorus release from sediments.

This investigation was conducted under the general supervision of Dr. John W. Keeley, Director, EL, and under the direct supervision of Dr. Richard E. Price, Chief, EPED.

At the time of publication of this report, Dr. Lewis E. Link was Acting Director of ERDC, and COL Robin R. Cababa, EN, was Commander.

This report should be cited as follows:

James, W. F., Barko, J. W., and Eakin, H. L. (1999). "Diffusive and kinetic fluxes of phosphorus from sediments in relation to phosphorus dynamics in Lake Pepin, Upper Mississippi River," Miscellaneous Paper W-99-1, U.S. Army Engineer Research and Development Center, Vicksburg, MS.

The contents of this report are not to be used for advertising, publication, or promotional purposes. Citation of trade names does not constitute an official endorsement or approval of the use of such commercial products. 


\section{Introduction}

Sediments transported into lakes and reservoirs can play an important role in regulating phosphorus $(\mathrm{P})$ dynamics and primary productivity by influencing nutrient concentrations in the water column through diffusive flux as bottom sediment and kinetic flux (adsorption-desorption processes) as suspended sediment. Quantifying these fluxes within the context of a P budget is essential for developing management strategies to control $\mathrm{P}$ and eutrophication. Much research has been devoted to evaluation of diffusive release of $\mathrm{P}$ from bottom sediments (Nürnberg 1984) and adsorption-desorpton fluxes of $\mathrm{P}$ from sediments resuspended into the water column via turbulence (Søndergaard, Kristensen, and Jeppesen 1992; Reddy, Fisher, and Ivanoff 1996). However, very little information exists that links watershed-derived suspended-sediment transport through rivers, lakes, and reservoirs to $\mathrm{P}$ adsorption/desorption processes and to the regulation of soluble P concentrations (Mayer and Gloss 1980; Froelich 1988). In particular, adsorption-desorption reactions via transported sediment may be the primary means of controlling $\mathrm{P}$ concentrations in the water column for water bodies receiving high suspended-sediment loadings. Since P is generally an important nutrient for phytoplankton growth in eutrophic systems, there is a need to examine and understand these $\mathrm{P}$ equilibrium processes and fluxes in relation to soluble $\mathrm{P}$ concentrations and overall primary productivity in aquatic systems.

Lake Pepin, a natural impoundment in the Upper Mississippi River (UMR), is eutrophic and exhibits high total and soluble $\mathrm{P}$ concentrations (means $=0.16$ and 0.09, respectively; James and Barko 1996) because of excessive loading from point and nonpoint sources. Control of $\mathrm{P}$ is presently being considered for the agriculturally dominated Minnesota River basin and the Metropolitan Wastewater Treatment Plant (Metro Plant), which both discharge into the Misssissippi River $\sim 50$ miles $^{1}$ upstream of Lake Pepin.

An unusual characteristic of $\mathrm{P}$ dynamics in this lake is the occurrence of net export of soluble reactive $\mathrm{P}$ (SRP) from the system during the summer months (Lung and Larson 1995; Maurer, Claflin, and Rada 1995), in spite of high external loadings of SRP. These patterns suggest that internal processes of $\mathrm{P}$ recycling/loading and $\mathrm{P}$ transformations between particulate and soluble phases

1 To convert miles (U.S. nautical) to kilometers, multiply by 1.852 . 
may be important in Lake Pepin. Seasonal P dynamics and external P loadings were examined in the UMR and Lake Pepin over a 3-year period (1994-96) to document in detail the occurrence of net SRP export from the system. Earlier information on internal P loading (James, Barko, and Eakin 1995) was expanded by estimating whole-lake diffusive $\mathrm{P}$ flux from profundal sediments in Lake Pepin as a function of temperature and redox using laboratory-based rates determined under controlled conditions. Kinetic flux of $\mathrm{P}$ to and from surface sediments deposited in Lake Pepin were examined under different soluble P equilibrium conditions. The objectives were to examine the importance of internal $\mathrm{P}$ loading rates via these two processes within the context of a $\mathrm{P}$ budget for the lake. 


\section{Methods}

\section{Study Site}

Lake Pepin (Table 1) is included as part of Pool 4 of the lock and dam system of the UMR (Figure 1) and receives inflows from a 122,000- $\mathrm{km}^{2}$ watershed (Minnesota Pollution Control Agency (MPCA) 1993a). There are three additional pools formed by locks and dams on the UMR upstream of Lake Pepin. Major tributary inputs to the UMR and Lake Pepin are the Mississippi, Minnesota, and St. Croix rivers. The Minnesota River discharges into Pool 2, and the St. Croix River discharges into Pool 3 of the UMR. The Metro Plant, located in St. Paul, MN, discharges into Pool 2. Minor tributary sources to Lake Pepin are the Cannon, Rush, and Vermillion rivers and Isabelle Creek. Minor wastewater treatment plants discharging directly into the Mississippi River and Lake Pepin are located in Red Wing and Lake City, MN, and Maiden Rock and Pepin, WI. Numerous other treatment plants discharge into the Minnesota and St. Croix rivers upstream of Lake Pepin (MPCA 1993a and b).

\begin{tabular}{|c|c|}
\hline \multicolumn{2}{|c|}{$\begin{array}{l}\text { Table } 1 \\
\text { Limnological Features of Lake Pepin }\end{array}$} \\
\hline Surface area ${ }^{1}$ & $93.4 \times 10^{6} \mathrm{~m}^{2}$ \\
\hline Volume $^{1}$ & $539 \times 10^{6} \mathrm{~m}^{3}$ \\
\hline Mean depth ${ }^{2}$ & $5.4 \mathrm{~m}$ \\
\hline Maximum depth ${ }^{2}$ & $17 \mathrm{~m}$ \\
\hline Width (variable) $)^{2}$ & $\sim 1.7-3.3 \mathrm{~km}$ \\
\hline Maximum fetch ${ }^{2}$ & $19 \mathrm{~km}$ \\
\hline Length $^{2}$ & $33.5 \mathrm{~km}$ \\
\hline Watershed area $^{2}$ & $121,966 \mathrm{~km}^{2}$ \\
\hline Residence time $^{2}$ & 19 days \\
\hline
\end{tabular}




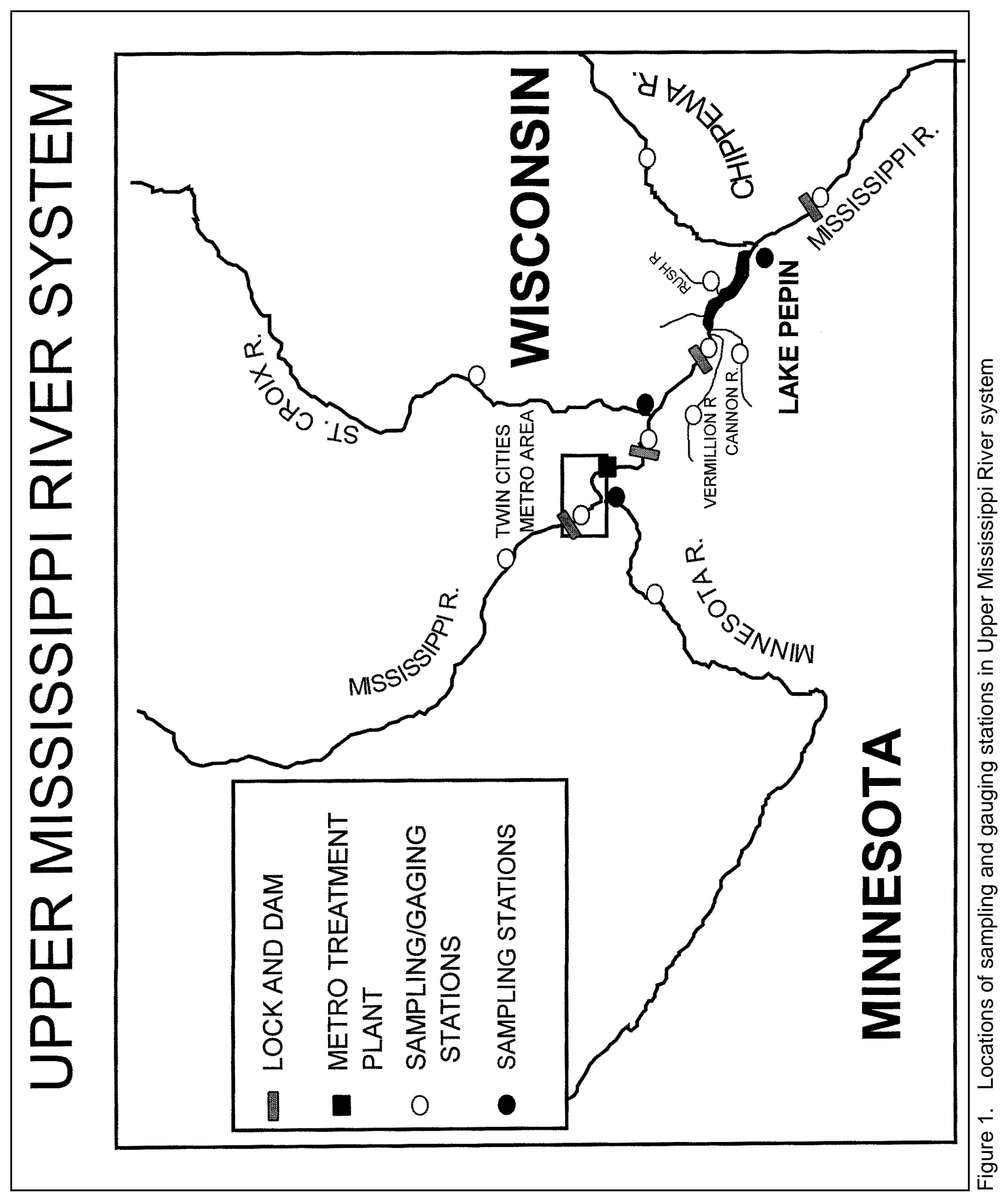




\section{Limnological Analysis}

Flow gauging stations (Figure 1), operated by the U.S. Geological Survey and the U.S. Army Engineer District, St. Paul, were established on the lock and dams and on the Minnesota, Mississippi, St. Croix, Cannon, and Vermillion rivers for loading determination. Flow and loading were also estimated for the Metro Plant, located in St. Paul, MN, and minor wastewater treatment plants located in the towns of Pepin, Red Wing, Maiden Rock, and Lake City. Precipitation and changes in pool elevation were measured at Lake City, MN, by the U.S. Army Corps of Engineers. Evaporation, which was negligible compared with other water fluxes, was estimated from standard evaporation tables. The hydrological budget for Lake Pepin was defined by the following equation: Change in Water Storage $=($ Gauged Inflows + Precipitation $)-($ Discharge + Evaporation $)$. Since discharges from Lake Pepin were not measured directly, discharge was estimated by difference after inserting measured values into the above equation.

Water samples were collected weekly to biweekly at each station over the period 1994-96 for analysis of suspended seston, total P, and SRP. For suspended seston, a known volume of lake water was filtered through a precombusted glass fiber filter (Gelman A/E) and dried to a constant weight at $105{ }^{\circ} \mathrm{C}$ (American Public Health Association (APHA) 1992). Samples for total P were predigested with potassium persulfate according to Ameel, Axler, and Owen (1993) before colorimetric determination on a Lachat QuikChem automated system (Lachat Method 10-115-01-1-A; Zellweger Analytics, Lachat Div., Milwaukee, WI). Water samples for analysis of SRP were filtered through a $0.45-\mu \mathrm{m}$ filter (Gelman Metricel) prior to colorimetric determination using automated procedures (Lachat Method 10-115-01-1-A). Annual and seasonal loadings of suspended seston and $\mathrm{P}$ from various sources were estimated using the program FLUX (Walker 1987).

Five stations were established along the longitudinal axis of Lake Pepin for limnological monitoring during the period 1994-96 (Figure 2). Water samples, retrieved with a Van Dorn water bottle (4-L capacity), were collected biweekly at the surface at Stations UM787.0 (Minnesota and Wisconsin channels) and UM764.5 and at 1-m intervals from the surface to within $0.5 \mathrm{~m}$ from the bottom at Stations UM781.0, UM775.0, UM771.0, and UM766.0 for suspended seston, total P, and SRP. Measurements of water temperature, dissolved oxygen, and $\mathrm{pH}$ at these same depths were collected in situ with a Hydrolab Surveyor III precalibrated against known buffers and Winkler titrations (APHA 1992).

\section{Evaluation of Rates of Internal Phosphorus Loading from Profundal Sediments in Lake Pepin}

Replicate sediment cores were collected using a Wildco KB sediment core sampler (Wildco Wildlife Supply Co.) from four stations in Lake Pepin 


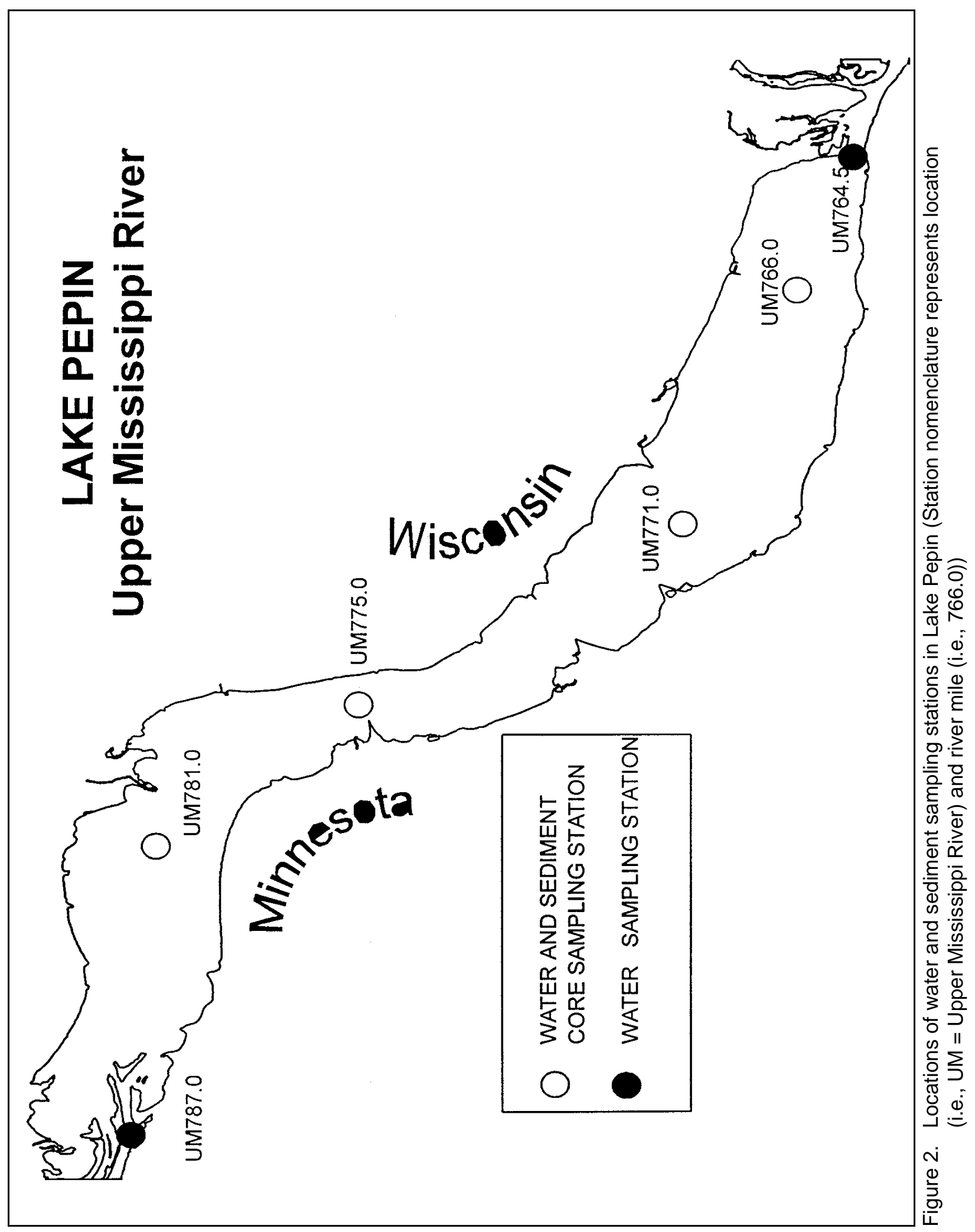


(UM766.0, UM771.0, UM778.0, and UM781.0) for examination of SRP release from profundal sediments under oxic and anoxic conditions for four different seasonal water-temperature conditions during 1996-97. A total of six sediment cores (three replicates for oxic release and three replicates for anoxic release) were collected at each site during a spring (May 1996; $11^{\circ} \mathrm{C}$ ), summer (July 1996; $24{ }^{\circ} \mathrm{C}$ ), autumn (September 1996; $18^{\circ} \mathrm{C}$ ), and winter (February 1997; ${ }^{\circ} \mathrm{C}$ ) period for analysis of rates of $\mathrm{P}$ release under different ambient watertemperature conditions.

Sediment cores collected in the field during each seasonal period were stored overnight under in situ temperature conditions before insertion into sediment incubation systems the next day. The sediment incubation systems were constructed according to James and Barko (1991) using the upper $10 \mathrm{~cm}$ of intact sediment and filtered lake water $(0.3 \mathrm{~L})$, collected from Lake Pepin. All sediment systems were incubated at the temperature-reflecting conditions in the field at the time of sediment collection. Three replicate sediment systems from each station were subjected to oxic conditions, using gentle bubbling with air, while an additional three replicates were subjected to anoxic conditions, using gentle bubbling with nitrogen. Samples were collected from the incubation systems at daily intervals, filtered through a $0.45-\mu \mathrm{m}$ filter (Nalge), and analyzed for SRP using automated techniques. Rates of SRP release from the sediments were calculated as the change in mass divided by the area of the sediment core incubation system and the number of days $\left(\mathrm{mg} \mathrm{m}^{-2} \mathrm{day}^{-1}\right)$.

Rates of P release from sediments in Lake Pepin were estimated over seasonal and annual time scales as a function of redox (i.e., oxic versus anoxic) and temperature conditions, using ranges in laboratory-derived rates of $\mathrm{P}$ release from the sediments and in situ measurements of temperature and dissolved oxygen collected at Stations UM781.0, UM775.0, UM771.0, and UM766.0 during 1994-96. Conditions were assumed to be anoxic when dissolved oxygen was less than $0.5 \mathrm{mg} / \mathrm{L}$. Rates of P release from sediments were estimated via the following regression equations for various temperature and redox conditions,

Oxic P release, $\mathrm{mg} \mathrm{m}^{-2}$ day $^{-1}=0.2107\left(\ln\right.$ temperature, $\left.{ }^{\circ} \mathrm{C}\right)-2.7594\left(\mathrm{r}^{2}=0.89\right)$ Anoxic P release, $\mathrm{mg} \mathrm{m}^{-2}$ day $^{-1}=0.1525\left(\ln\right.$ temperature, $\left.{ }^{\circ} \mathrm{C}\right)-0.1636\left(\mathrm{r}^{2}=0.89\right)$

Rates were weighted with respect to sediment area at each depth interval and summed to obtain a whole-lake estimate of $\mathrm{P}$ release from the sediments.

\section{Evaluation of Phosphorus Adsorption- Desorption by Sediments in Lake Pepin}

Surface sediment samples were collected in the vicinity of River Miles 766, 775, and 781 (Figure 2) for examination of phosphorus adsorption-desorption. Sediment sampling at other stations between River Miles 846 and 796 were also attempted. However, fine sediments were generally not present at these stations. The upper $1 \mathrm{~cm}$ of sediment was extruded and immediately homogenized in air 
to create oxic conditions. Sediments were then periodically homogenized for at least $12 \mathrm{hr}$ prior to sorption experiments to maintain oxic conditions. After the sediments were centrifuged at 2,500 rpm for $5 \mathrm{~min}$ to remove excess pore water, the equivalent of $500 \mathrm{mg}$ dry mass/L of wet sediment was suspended into lake water ranging in SRP concentration from 0 to $1 \mathrm{mg} / \mathrm{L}$. The concentration of suspended sediment fell within the range of values observed for Minnesota River inflows, which contribute substantially to the sediment budget of Lake Pepin (see results). Surface water from Eau Galle Reservoir, Wisconsin, was used as the lake-water medium because it was phosphate free and exhibited very similar cationic strength, conductivity, and $\mathrm{pH}$ to that of surface water in Lake Pepin. Phosphate as $\mathrm{KH}_{2} \mathrm{PO}_{4}$ was added to the lake water prior to exposure with sediment to adjust the $\mathrm{P}$ concentration. Individual centrifuge bottles, representing different concentration intervals, with lake water and suspended sediment were shaken continuously at $150 \mathrm{rpm}$ on a shaker table over a $24-\mathrm{hr}$ period. Samples were removed and filtered through a $0.45-\mu \mathrm{m}$ filter for SRP analysis.

The native adsorbed phosphorus (NAP) at phosphate equilibrium and linear adsorption coefficient (LAC) were determined using regression analysis of the $\mathrm{P}$ desorbed versus the final phosphate equilibrium concentration at low $\mathrm{P}$ concentrations (Froelich 1988). The equilibrium P concentration (EPC), defined as the $\mathrm{P}$ concentration where no net adsorption or desorption takes place, was calculated as:

$$
\mathrm{EPC}=\mathrm{NAP} / \mathrm{LAC}
$$




\section{Results}

\section{Hydrological Conditions}

During the years 1994-96, the Mississippi River provided the greatest annual water income (38-42 percent) to Lake Pepin followed closely by the Minnesota River (26-32 percent; Figure 3). The St. Croix River accounted for 21 to 27 percent of the annual water income to the lake. All other sources accounted for $<5$ percent of the annual water income to the lake.

Seasonally, inflows to Lake Pepin increased markedly between mid-March and early June during periods of spring snowmelt and storms, reaching maxima in excess of 1,500 cms during all years (Figure 4). Numerous smaller peaks in inflow to Lake Pepin occurred between late June and October of 1994 and 1995. The year 1996 was an exception to this summer pattern, as flows declined substantially to $<500 \mathrm{cms}$ between July and late September. Summer low-flow conditions also occurred briefly in late July and late August 1994 and early June and early September 1995. During winter months (November through February), inflows declined to nominal rates (i.e., <500 cms; Figure 4).

During periods of elevated inflow (i.e., $>500 \mathrm{cms}$ ), the residence time of Lake Pepin usually declined to 10 days or less (Figure 4). During periods of nominal inflow, the residence time of the lake usually fluctuated between about 10 and 30 days. Residence time was usually greatest during the winter period (January through March). However, residence time also increased substantially (>10 days) in conjunction with low-flow periods during the summer of all years. In particular, residence times were high between July and September 1996 and reached a peak of nearly 30 days in September 1996 during an extended period of low flow.

\section{Suspended Seston Dynamics}

During all years, the Minnesota River accounted for most (77-84 percent) of the annual suspended seston load to the UMR (Figure 5). The Mississippi River accounted for only 12-17 percent and all other inflows each accounted for $<5$ percent of the annual suspended seston load to the UMR (Figure 5). 


\section{ANNUAL WATER INCOME TO LAKE PEPIN}
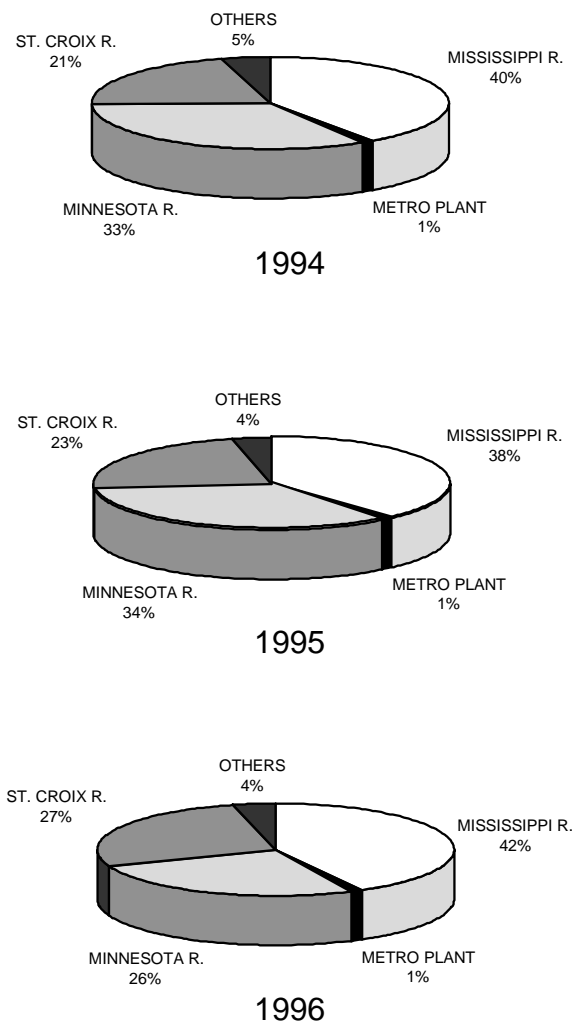

Figure 3. Relative contributions (percent) by various sources to annual water income of Lake Pepin during years 1994-96

Annual and summer suspended seston retention was very high (>70 percent) in Lake Pepin (Table 2), indicating substantial net sedimentation.

Seasonal and longitudinal patterns in mean concentrations of suspended seston in Lake Pepin (Figure 6) generally followed seasonal changes in external loadings/discharges of this variable. During spring peaks in the hydrograph (Figure 4) and during the summer period, suspended seston concentrations in the lake were greatest in the headwater region (i.e., UM787.0) and lowest at 


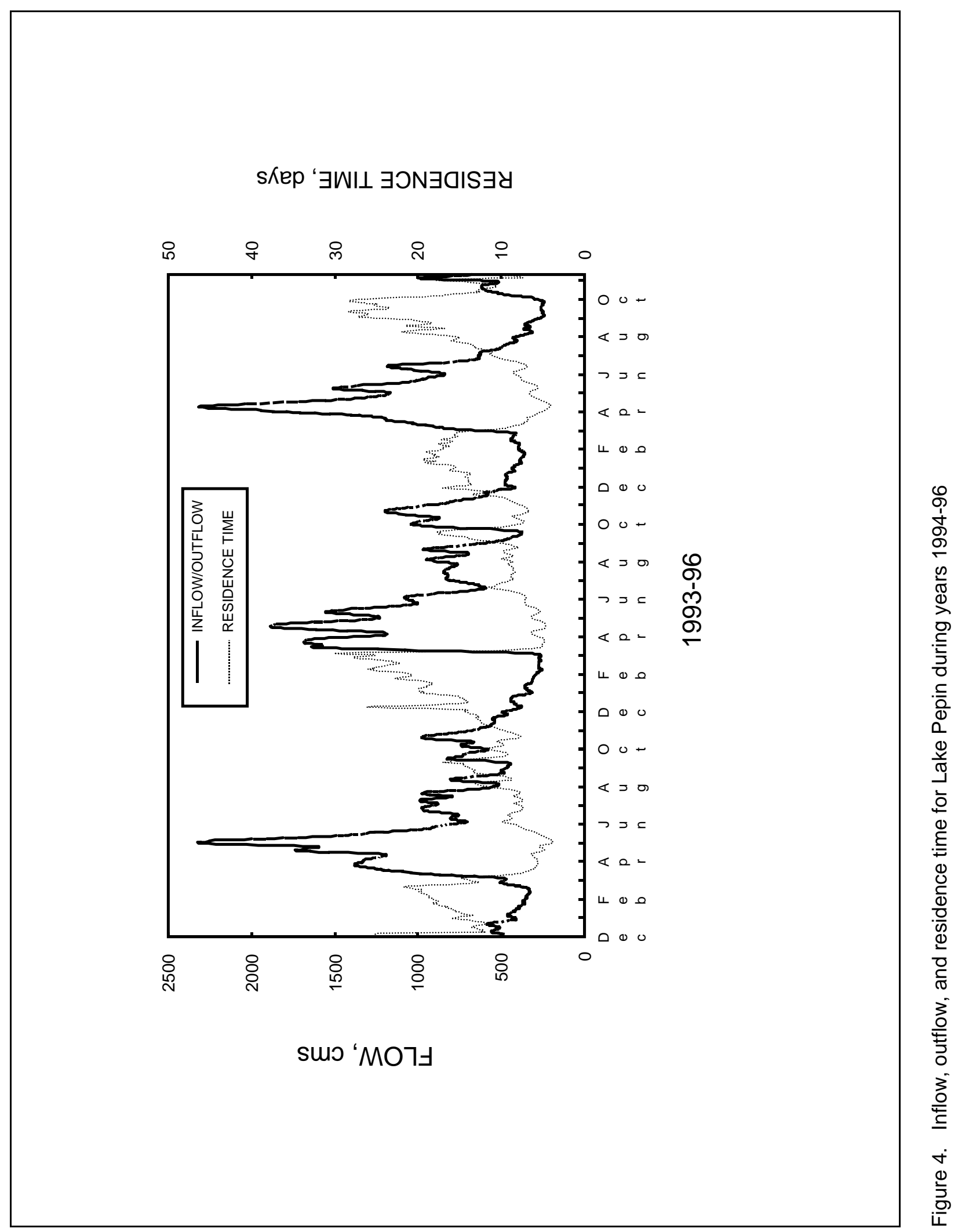




\section{ANNUAL SUSPENDED SESTON LOADINGS RELATIVE CONTRIBUTIONS}
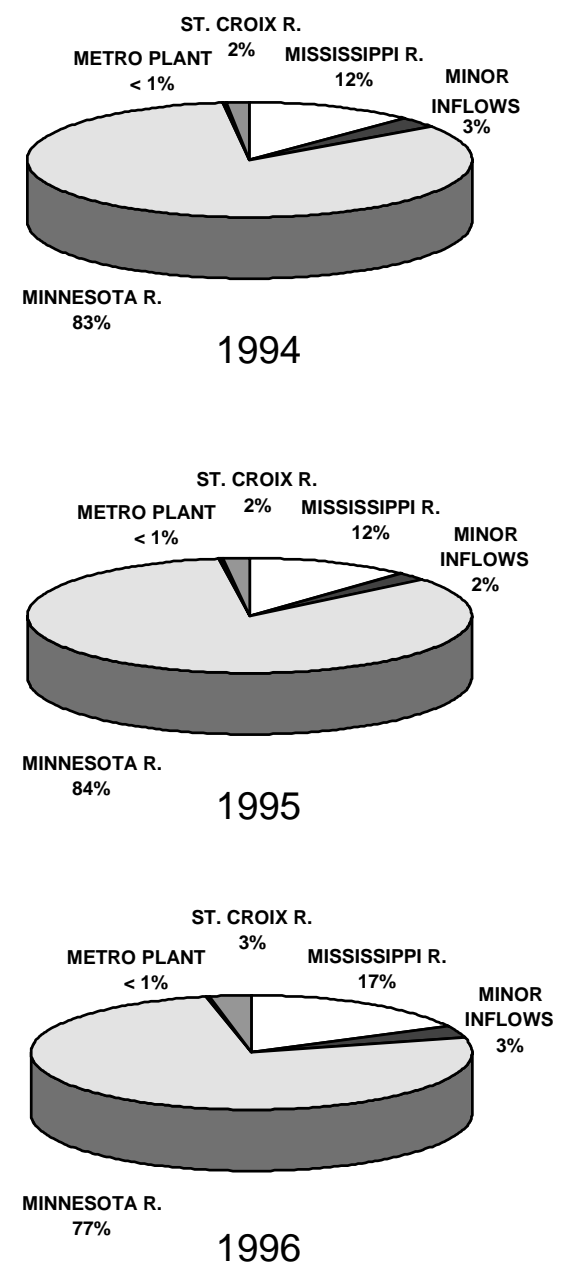

Figure 5. Relative contributions (percent) by various sources to annual suspended seston load of Lake Pepin during years 1994-96 


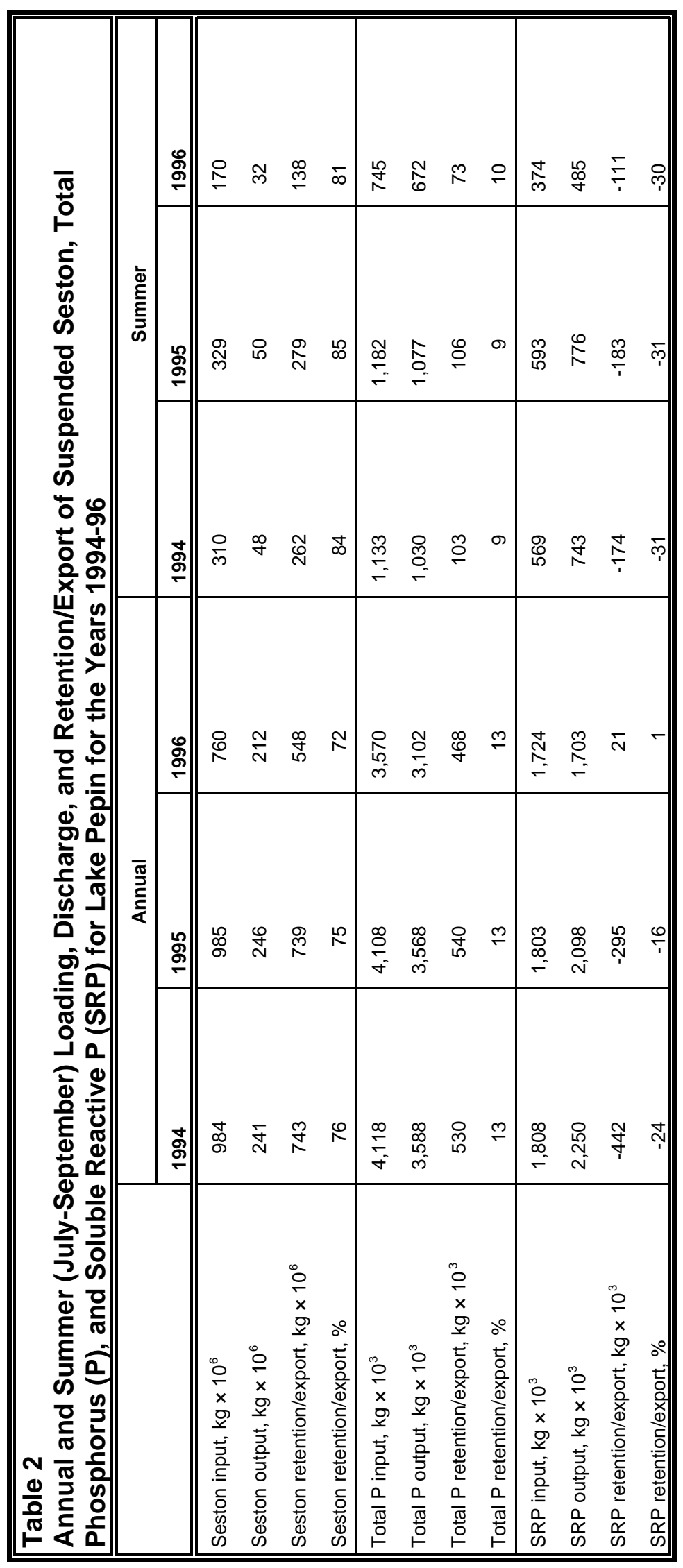


UM766.0 (Figure 6) in conjunction with storm inflows (Figure 4). Longitudinal gradients in concentration were generally most pronounced between UM787.0 and UM775.0, suggesting that greatest riverine influences and sedimentation occurred in the headwaters. During periods of low inflow and loading (i.e., November through February), longitudinal gradients in suspended seston greatly diminished (Figure 6).

\section{Phosphorus Dynamics}

The relative contributions to the total P load to the UMR were dominated by the Minnesota River (38 to 48 percent; Figure 7). However, the Metro Plant and the Mississippi River also contributed substantially, accounting for $\sim 24$ and 21 percent of the total P load to the UMR, respectively (Figure 7). Relative daily contributions of total $\mathrm{P}$ to the lake were flow dominated, with the Minnesota River accounting for $>50$ percent of the loading during periods of elevated inflow. During periods of lower inflow and during ice cover, relative daily contributions by the Metro Plant and Mississippi River increased substantially, while relative daily contributions by the Minnesota River declined to $<50$ percent of the total $\mathrm{P}$ load. Overall, Lake Pepin was a sink for total $\mathrm{P}$, retaining $\sim 13$ and $\sim 9$ percent of the load on an annual and summer basis, respectively (Table 2 ).

Relative contributions to the annual SRP load to the UMR were dominated by the Metro Plant during all years, accounting for 42 to 48 percent of the annual load (Figure 8). The Minnesota River also contributed considerably, accounting for 27 to 36 percent of the annual load. The Mississippi River accounted for only 12 percent, while other inputs collectively accounted for only about 6 percent of the annual load to the UMR (Figure 8). In particular, the St. Croix River, which contributed substantial water income to Lake Pepin, made very minor contributions to the SRP load to the UMR. On a seasonal basis, contributions by the Minnesota River exceeded 50 percent of the SRP load to the UMR primarily during major peaks in the hydrograph. The Metro Plant was usually the major contributor of SRP (i.e., 40-60 percent) during most other seasonal periods, particularly during periods of low flow such as winter months. Unlike suspended seston and total P, Lake Pepin exhibited net export of SRP during most years, both on an annual and seasonal basis (Table 2).

SRP dynamics in the inflow and outflow of Lake Pepin exhibited a complex seasonal pattern over the 3-year study period (Figure 9). In conjunction with peaks in flow during mid-March through May-June of all years, SRP concentrations declined to a minimum in both the inflow and outflow (Figure 9a). Although flows were typically highest during the spring, SRP loadings and discharges were low (Figure 9b), and little net retention/export occurred (Figure 9c), relative to summer loadings, as a result of low SRP concentrations in the inflow. This pattern was associated with the occurrence of spring diatom blooms (see James and Barko 1995, 1996), suggesting possible algal uptake of SRP for growth. Concentrations of SRP also declined to minimal 


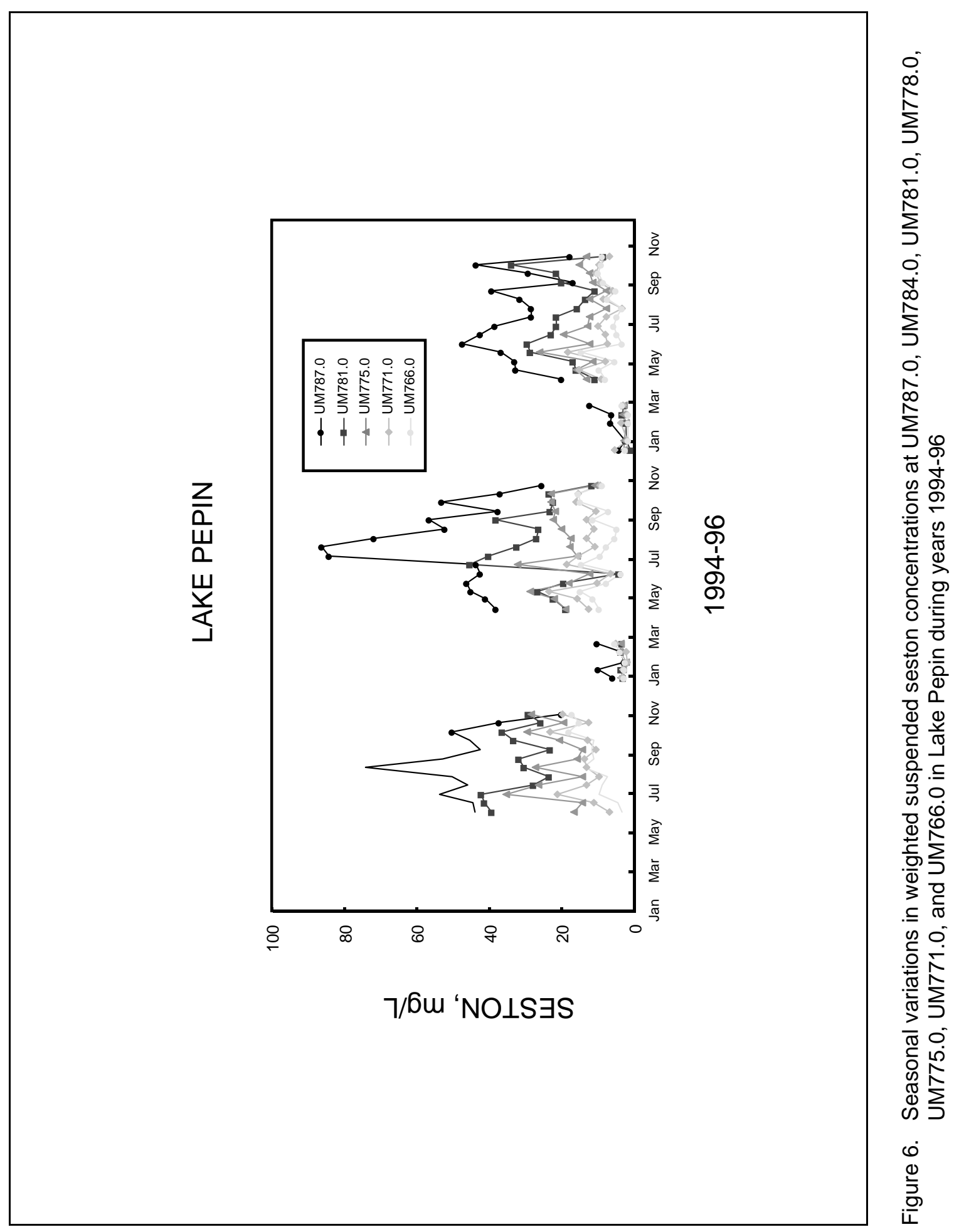




\section{ANNUAL TOTAL PHOSPHORUS LOADING RELATIVE CONTRIBUTIONS}
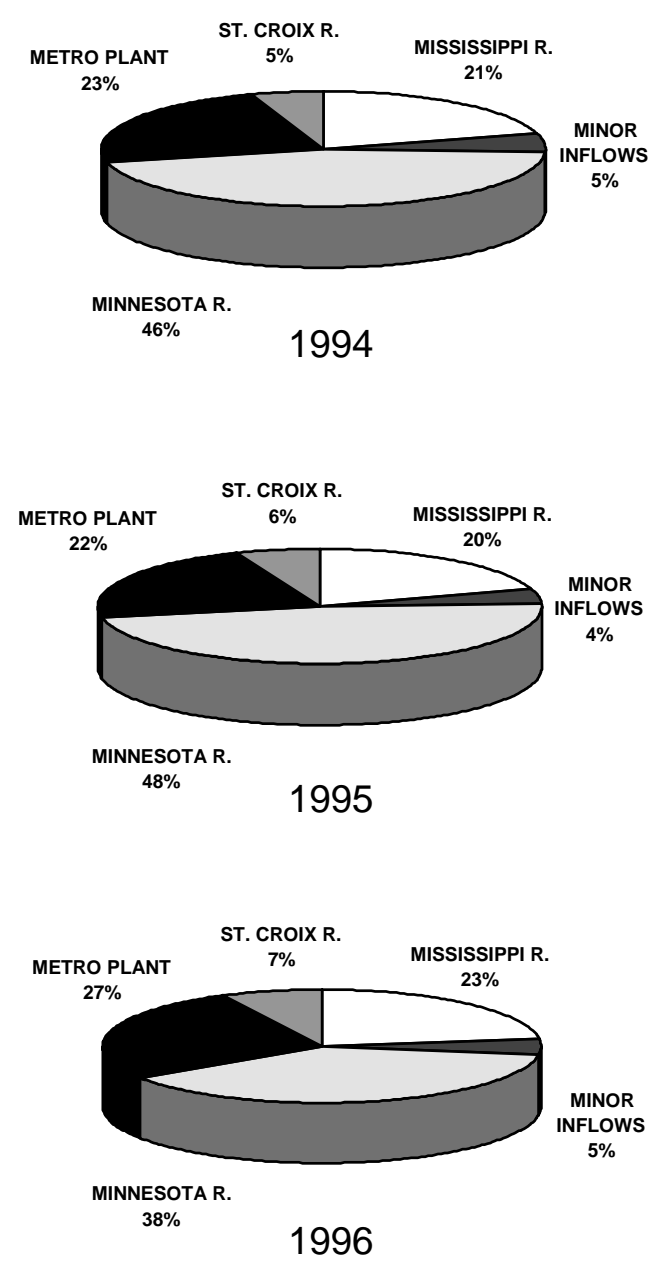

Figure 7. Relative contributions (percent) by various sources to annual total phosphorus load of Lake Pepin during years 1994-96 


\section{ANNUAL SOLUBLE REACTIVE P LOADINGS RELATIVE CONTRIBUTIONS}
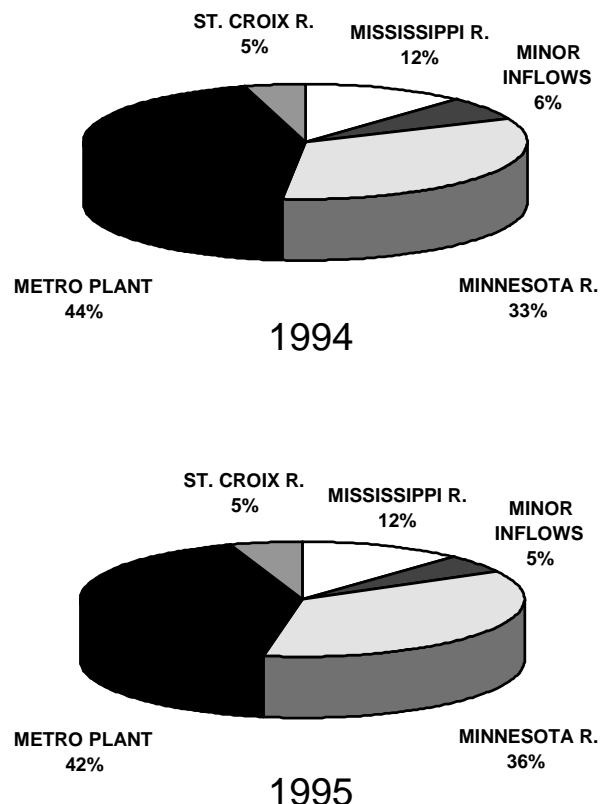

1995

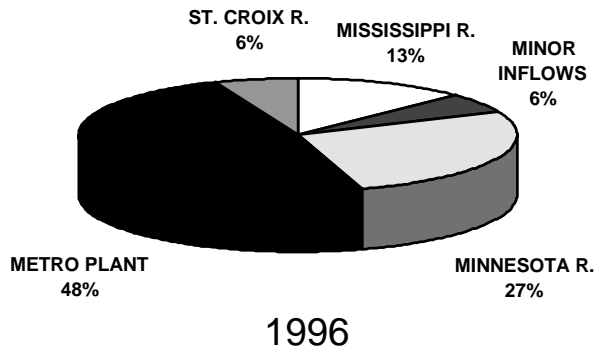

Figure 8. Relative contributions (percent) by various sources to annual soluble reactive phosphorus (SRP) load of Lake Pepin during years 1994-96 
LAKE PEPIN INFLOW/OUTFLOW
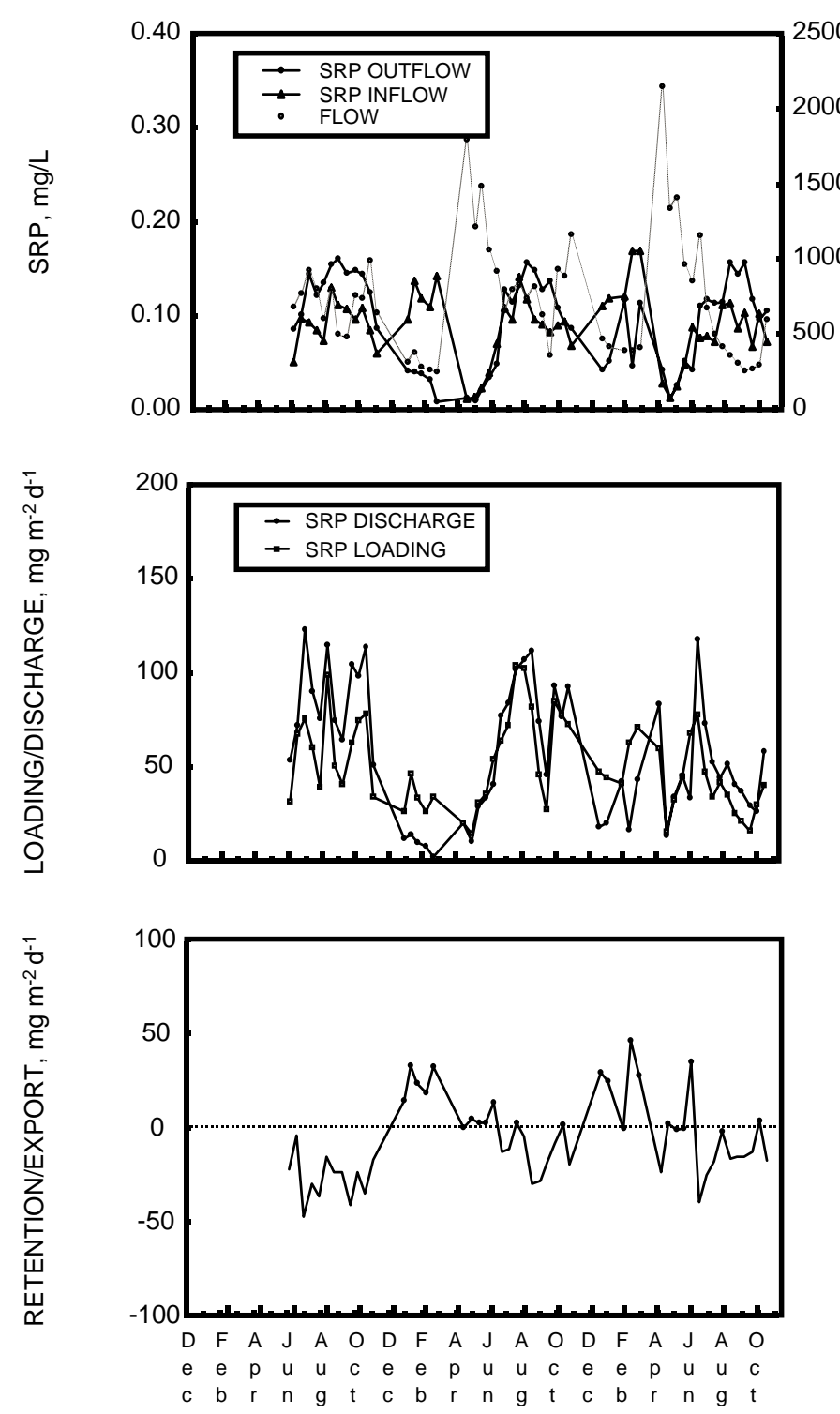

1993-96

Figure 9. Seasonal variations in (a) SRP concentration and flow, (b) SRP loading and discharge, and (c) net SRP retention/export for Lake Pepin during years 1994-96 (Retention/export is calculated as SRP loading minus discharge. A positve rate represents retention, while a negative rate represents export) 
values upstream of Lake Pepin in the Mississippi River at Lock and Dam 1, the Minnesota River at Fort Snelling, MN, and the St. Croix River at Prescott, WI, ${ }^{1}$ suggesting possible dilution, in addition to uptake by algae, as a result of high flows containing low SRP concentrations during the spring.

During the winter ice-covered months of all years, when loadings and flow were nominal and residence times exceeded 10 days, net retention of SRP (as sediment or algal biomass) occurred in Lake Pepin (Figure 9c) as concentrations (Figure 9a), and, thus, loadings (Figure 9b) were greater in the inflow than in the outflow. During the summer months (primarily July through September), in conjunction with greater temperatures, higher loadings and flows, and lower residence times, Lake Pepin exported SRP (Figure 9c), as concentrations were greater in the outflow than in the inflow (Figure 9a).

Within Lake Pepin, mean total P concentrations were typically greatest from mid-June through October of all years (Figure 10a), coinciding with periods of elevated external $\mathrm{P}$ loading and the occurrence of high phytoplankton biomass (see James and Barko 1995, 1996). Although longitudinal gradients in mean concentrations were usually not pronounced during the summer months, mean concentrations of total P were generally greater at UM787.0 and lower at downstream stations (Figure 10a), indicating overall net sedimentation. Exceptions to this pattern occurred in August 1996 when total P concentration in the outflow exceeded concentrations in the inflow during a period of low flow. Concentrations of total $\mathrm{P}$ were low on a lakewide basis during periods of high inflow between March and May of all years, consistent with concentration patterns observed in the inflows to Lake Pepin during these same periods.

SRP concentrations in Lake Pepin exhibited a similar seasonal pattern to that of total $\mathrm{P}$, with peaks in concentration coinciding with elevated flows in the summer and lower concentrations occurring during the high-flow periods of March through May (Figure 10b). In contrast to longitudinal variations observed for total P, however, mean concentrations of SRP were usually lowest at UM787.0, with pronounced longitudinal gradients of increasing mean concentrations toward UM766.0 during the summer (Figure 10b). This pattern of increasing mean concentration from headwaters to outflow reflected similar patterns observed for SRP external loading and discharge (Figure 9a). During the winter months, the opposite pattern occurred, as concentrations were greatest at UM787.0 and less at downstream locations (Figure 10b), reflecting similar loading/discharge patterns.

Differences in the longitudinal patterns in mean total P, and SRP concentrations were also reflected in the percentage ratio between these two variables (SRP/total P; Figure 10c). During the spring high-flow period, SRP accounted for a minor portion ( $<10$ percent) of the total $\mathrm{P}$, and longitudinal differences in the ratio from headwaters to the outflow were not observed. During the summer period (July-September), SRP represented about

1 Unpublished data, William F. James, John W. Barko, and Harry L. Eakin, Environmental Laboratory, U.S. Army Engineer Research and Development Center, Vicksburg, MS. 

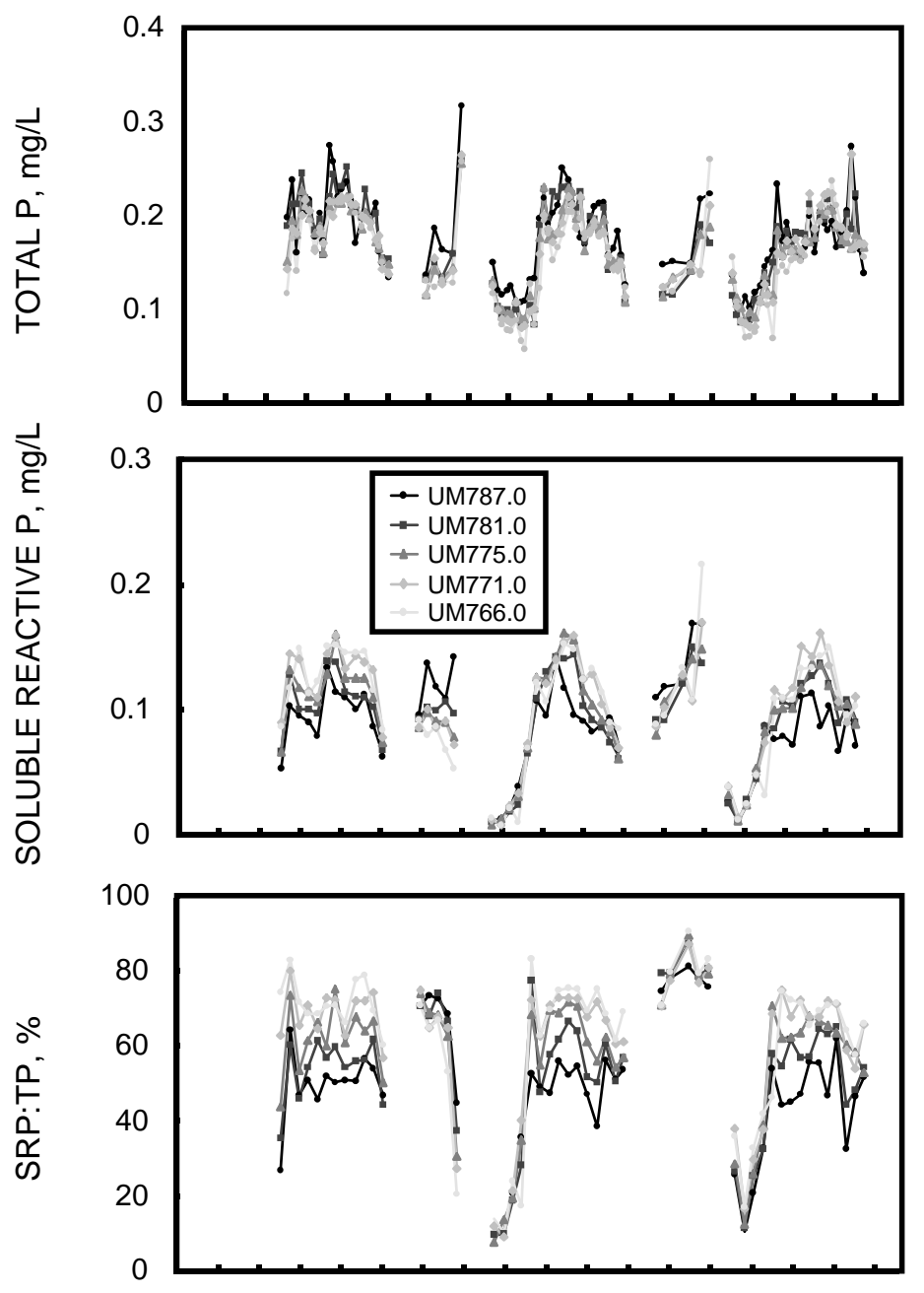

Jan Mar May Jul Sep Nov Jan Mar May Jul Sep Nov Jan Mar May Jul Sep Nov

1994-96

Figure 10. Seasonal variations in (a) total $P,(b)$ soluble reactive $P$, and (c) SRP:TP in Lake Pepin during years 1994-96 at Stations UM787.0, UM781.0, UM775.0, UM771.0, and UM766.0 
40-60 percent of the total $\mathrm{P}$ concentration at UM787.0, reflecting higher mean total P (Figure 10a) and lower mean SRP (Figure 10b) concentrations of the inflow. The SRP/total P ratio increased to 60-80 percent at downstream locations (Figure 10c), reflecting longitudinal decreases and increases in total $\mathrm{P}$ and SRP concentrations in Lake Pepin, respectively (Figure 10a and b). During the winter months, SRP also constituted a large proportion of the total P in Lake Pepin (up to 80 percent; Figure 10c).

Vertically in the water column, SRP concentrations also exhibited a trend of increasing concentration throughout the water column from headwaters to the outflow during the summer (Figure 11a). During periods of temporary anoxia in the summer, which occurred rarely, ${ }^{1}$ gradients of slightly higher SRP were observed near the sediment surface, suggesting possible internal P loading from the sediments (Figure 11b).

Seasonal dynamics in SRP concentrations in the UMR (from Lock and Dam 1 to the outflow of Lake Pepin) during the summer months exhibited a complex bimodal pattern (Figure 12). In general, SRP concentrations for the Mississippi River at River Mile 847 were usually low ( $<0.05 \mathrm{mg} / \mathrm{L}$ ). SRP increased to 0.025 to $0.050 \mathrm{mg} / \mathrm{L}$ in Pool 2 in the vicinity of River Mile 840 in conjunction with inflows from the Minnesota River. Substantial increases in concentration $(>0.10 \mathrm{mg} / \mathrm{L}$ ) occurred in the vicinity of the Metro Plant (located at River Mile 835) and at the outflow of Pool 2 (River Mile 815). Associated with inflows containing low concentrations of SRP from the St. Croix River (River Mile 809) was a decline in SRP concentration in Pool 3, suggesting dilution of SRP. SRP concentrations then increased linearly from the headwaters of Pool 4 to the outflow of Lake Pepin, reflecting patterns observed for SRP loading/discharge in the lake. The observation of intermittent SRP gradients near the sediment surface (Figure 11b) coupled with longitudinal increases in SRP from headwaters to outflow in Lake Pepin during the summer suggested that internal $\mathrm{P}$ loading from the profundal sediments and/or adsorptiondesorption processes between suspended sediment entering Lake Pepin and aqueous phases may be important components of the P budget of this lake.

\section{Internal Phosphorus Loading from Profundal Sediments in Lake Pepin}

Laboratory-derived rates of $\mathrm{P}$ release from sediments in Lake Pepin increased with increasing temperature under oxic and anoxic conditions (Figure 13). Under oxic conditions, rates of $\mathrm{P}$ release from sediments ranged from $-0.3 \mathrm{mg}$ $\mathrm{m}^{-2}$ day $^{-1}$ at $2{ }^{\circ} \mathrm{C}$ to $10.8 \mathrm{mg} \mathrm{m}^{-2}$ day $^{-1}$ at $24{ }^{\circ} \mathrm{C}$. Under anoxic conditions, rates of $\mathrm{P}$ release from sediments were 3 to 6 times greater than those rates determined under oxic conditions, ranging from $1.2 \mathrm{mg} \mathrm{m}^{-2}$ day $^{-1}$ at $2{ }^{\circ} \mathrm{C}$ to $29.8 \mathrm{mg} \mathrm{m}^{-2} \mathrm{day}^{-1}$ at $24{ }^{\circ} \mathrm{C}$. When transformed logarithmically, rates of $\mathrm{P}$ release under both oxic

\footnotetext{
1 Unpublished data, William F. James, John W. Barko, and Harry L. Eakin, Environmental Laboratory, U.S. Army Engineer Research and Development Center, Vicksburg, MS.
} 

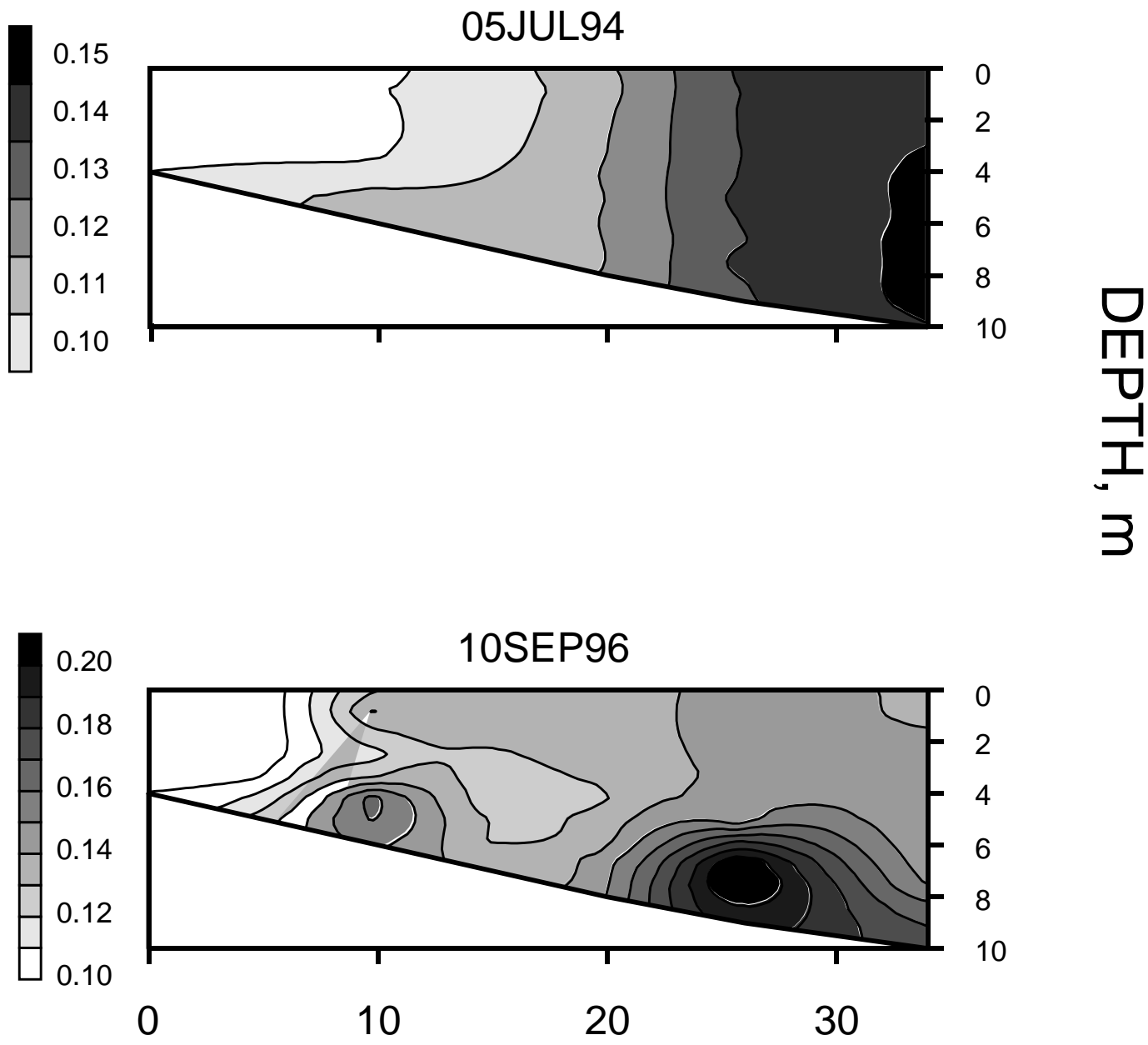

DISTANCE, $\mathrm{km}$

Figure 11. Longitudinal and vertical variations in SRP in Lake Pepin on (a) 05 July 1994 and (b) 10 September 1996 


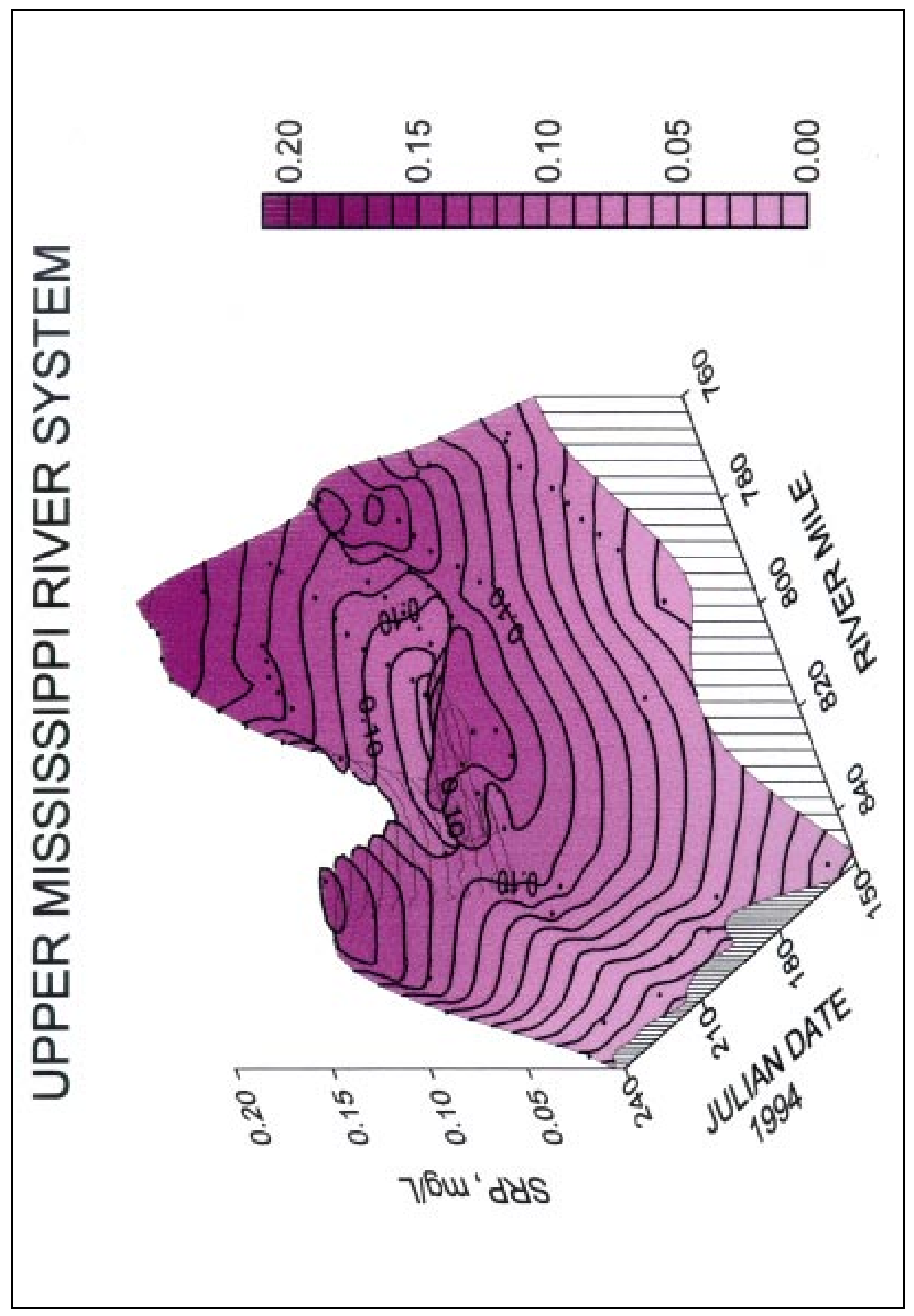

$\stackrel{\oplus}{=}$

흔 옹

오 흠

守文

赵䒕

$\cong$

立起离

$\stackrel{\bar{\Phi}}{\geq}$ 음

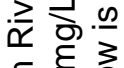

돈.

क ष

흐 of

뜬 $\frac{2}{x} \cdot \frac{1}{2}$

등 힝

○一

잏

율 일

. రิ

들 윰 $\sum_{\infty}^{\infty}$

สัธ ส

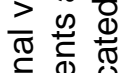

듀

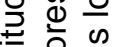

등 힌

을 올.

ฮั ঠे 志

즌 $\frac{1}{0} \frac{\pi}{2}$

어웛

ळ

पक के

号守

읃 은 $\sum_{0}^{\infty}$

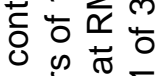

む) Ð

站空

임 


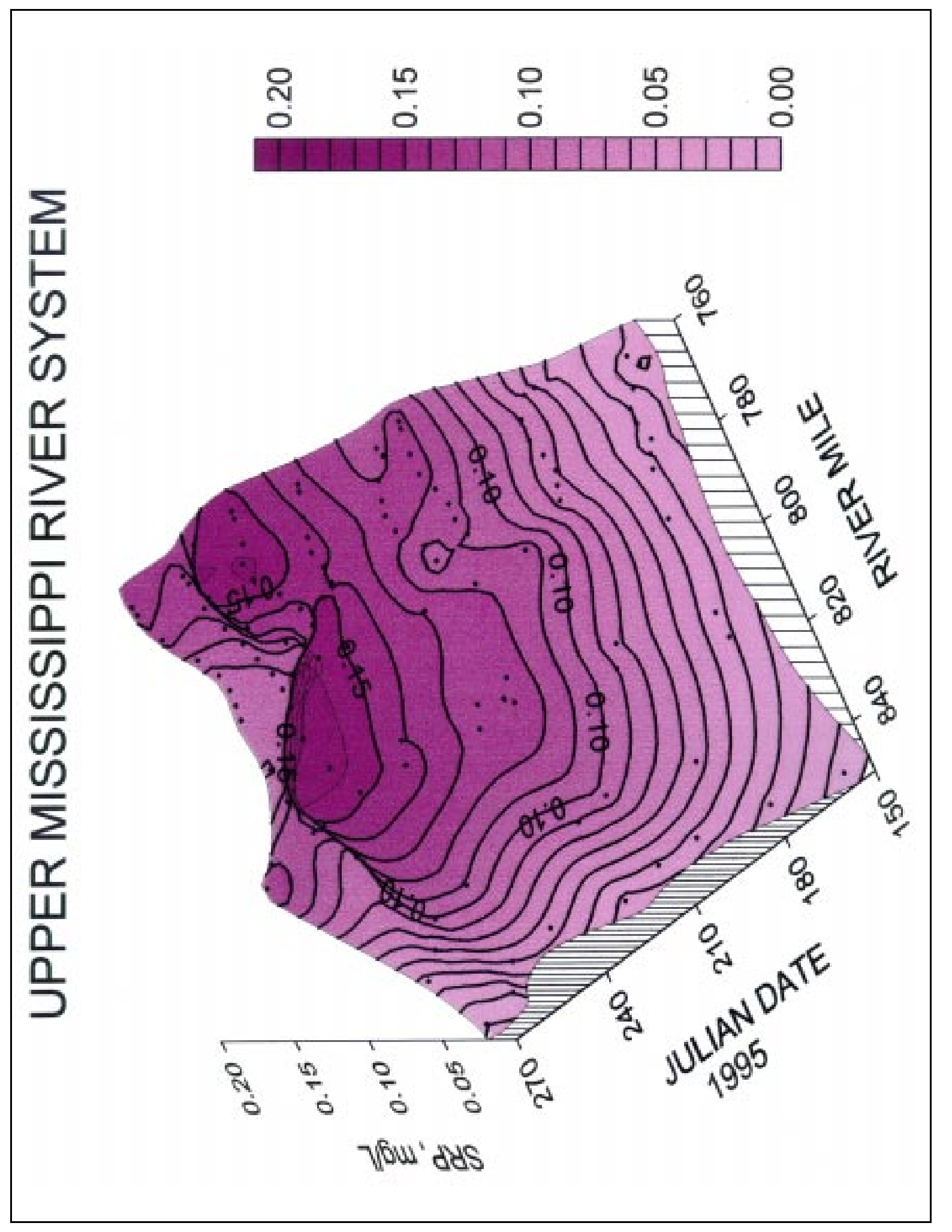

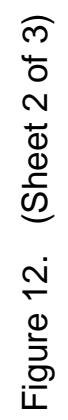




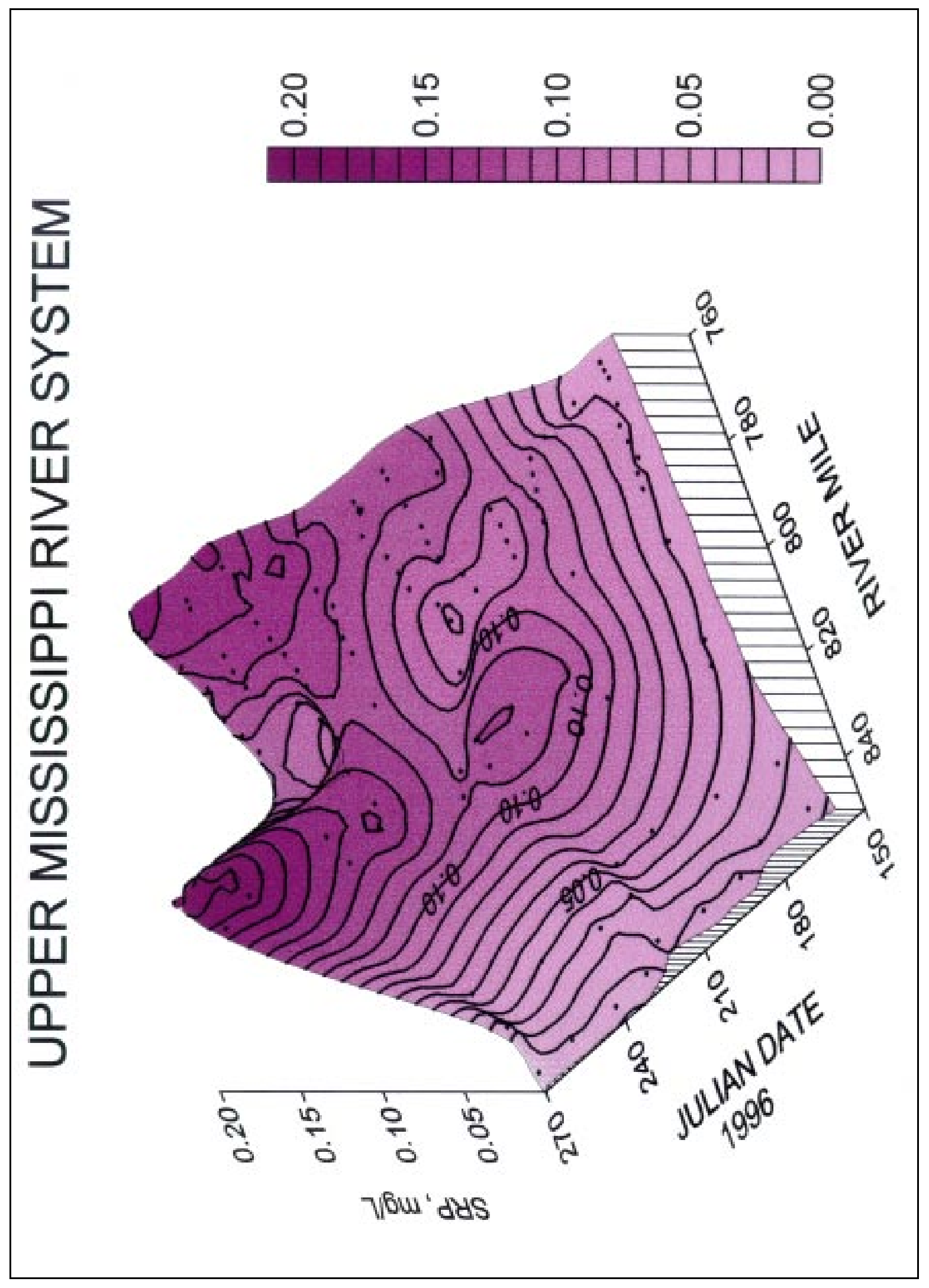

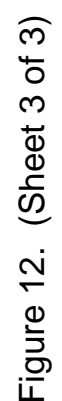



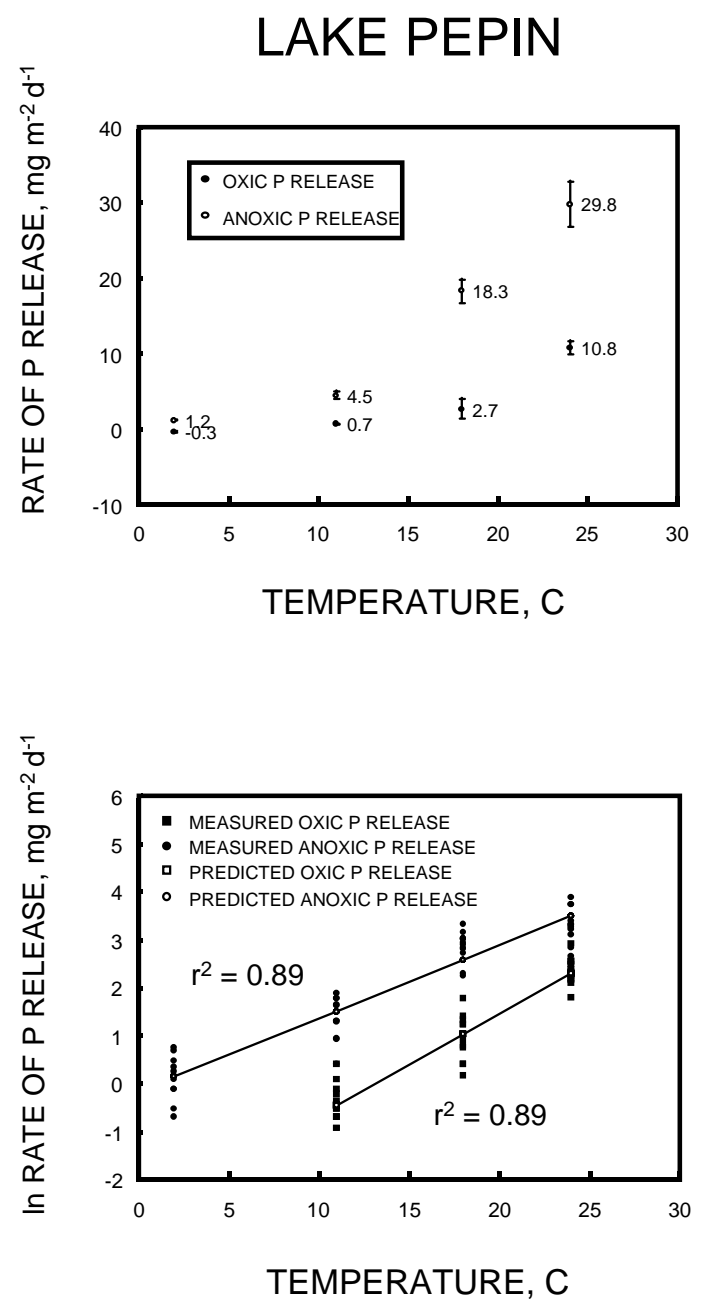

Figure 13. Variations in laboratory-derived mean $( \pm 1$ S.E.) rates of phosphorus $(\mathrm{P})$ release from sediments under oxic and anoxic conditions as a function of temperature for sediment collected in Lake Pepin

and anoxic conditions were strongly related to variations in temperature $\left(\mathrm{r}^{2}=\right.$ $0.89)$.

For all years, the whole-lake rate of $\mathrm{P}$ release from sediments, estimated via regression equations (see methods), varied primarily as a function of temperature, as rates were greatest during the summer months and minimal during the winter (Figure 14). Estimated whole-lake rates of $\mathrm{P}$ release varied 


\section{LAKE PEPIN}

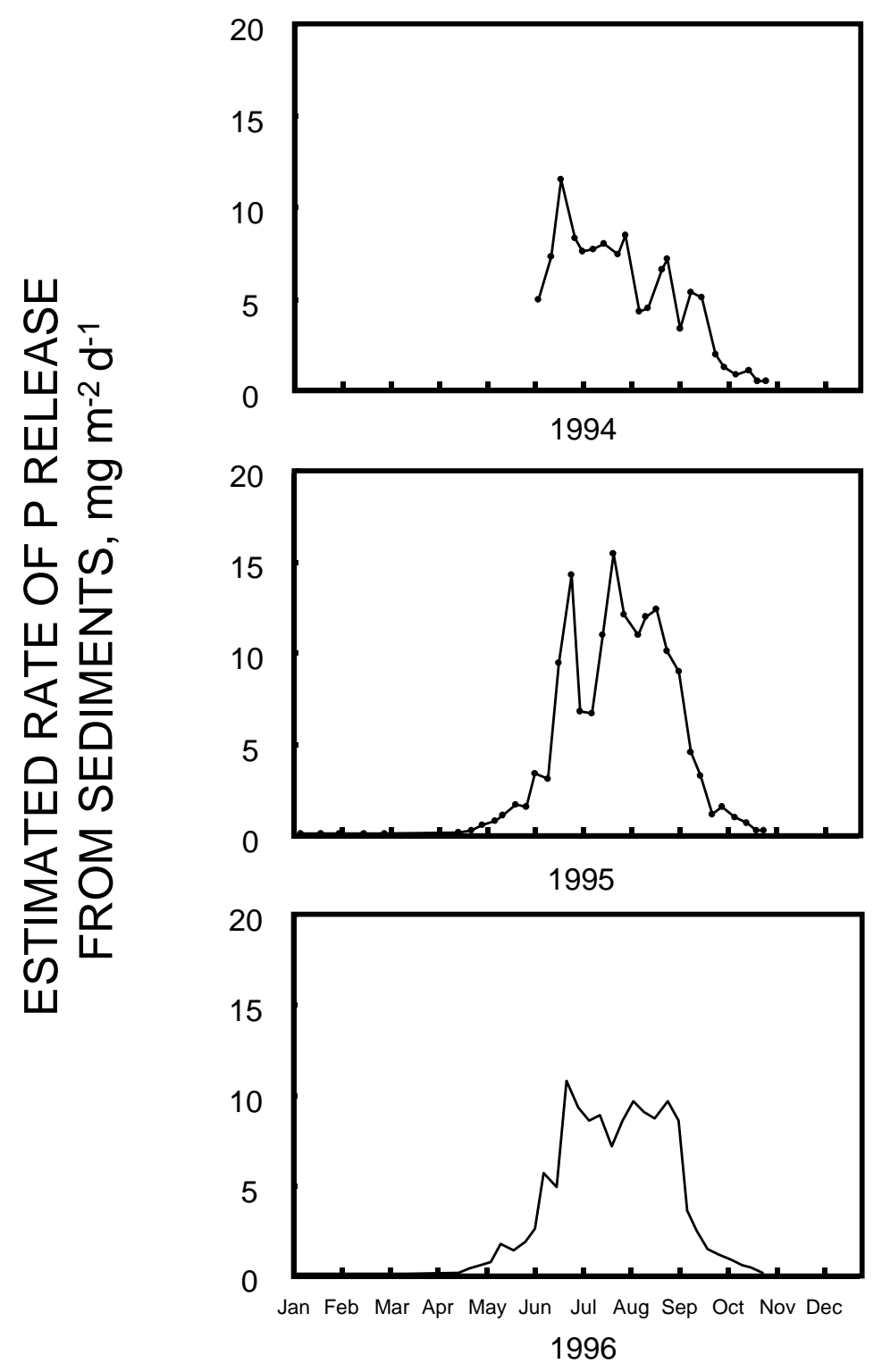

Figure 14. Seasonal variations in estimated whole-lake rate of phosphorus $(P)$ release from sediment in Lake Pepin in 1994-96 (Rates were estimated using in situ measurements of temperature and dissolved oxygen and regression equations (see methods)) 
from $0.1 \mathrm{mg} \mathrm{m}^{-2}$ day $^{-1}$ during the winter to peaks in rates exceeding $10 \mathrm{mg} \mathrm{m}^{-2}$ day $^{-1}$ during late June through August of all years. During the unusually hot summer of 1995, peaks in the estimated whole-lake rate of $P$ release from sediments exceeded $15 \mathrm{mg} \mathrm{m}^{-2}$ day $^{-1}$ reflecting higher water temperatures. Anoxic conditions appeared to play a minor role in regulating the rates of $\mathrm{P}$ release from sediments, as anoxia was detected in the bottom waters rarely.

\section{Phosphate Adsorption and Desorption from Sediments in Lake Pepin}

Oxic surface sediments in Lake Pepin exhibited P desorption at low concentrations of SRP, and P adsorption as SRP concentrations increased to $>\sim 0.25 \mathrm{mg} / \mathrm{L}$ (Figure 15). The calculated 24-hr EPC between sediments and the aqueous phase and NAP was high (Table 3). It appeared that longitudinal increases in SRP concentrations in the water column of Lake Pepin (Figure 10b) were approaching the 24-hr EPC (i.e., $0.162 \mathrm{mg} / \mathrm{L}$; Table 3) during periods of moderate to low flow in the summer, suggesting some regulation of $\mathrm{P}$ dynamics via adsorption-desorption of $\mathrm{P}$ from suspended seston entering Lake Pepin.

\section{Budgetary Analysis}

Through budgetary analysis the possibility was explored that internal $\mathrm{P}$ loading from profundal sediments and adsorption-desorption processes in the water column were contributing to SRP dynamics in the lake and net SRP export during summer periods (Table 4). Because concentrations of SRP in the headwaters were low in relation to the calculated EPC of sediments, a rate of $\mathrm{P}$ desorption was estimated, normalized with respect to lake surface area, for suspended seston entering Lake Pepin in the summer (Table 2), using mean concentrations of SRP in the headwaters (Figure 10) and the 24-hr LAC (Table 3). For the summers of 1994-96, the estimated rate of $\mathrm{P}$ desorption ranged from 2.3 to $3.7 \mathrm{mg} \mathrm{m}^{-2} \mathrm{day}^{-1}$ (Table 4). These rates were high compared with rates of internal $P$ loading from anoxic sediments, measured in a variety of eutrophic lakes (Nürnberg et al. 1986). Rates of internal P loading from profundal sediments were $\sim 1.5$ to 3 times greater than estimated rates of $\mathrm{P}$ desorption in the water column (Table 4). When both kinetic and diffusive rates were combined, measured internal loading from the sediments (both via the lake bottom and in the water column) accounted for $\sim 50$ to 75 percent of the net $P$ export from the system during the summer. 


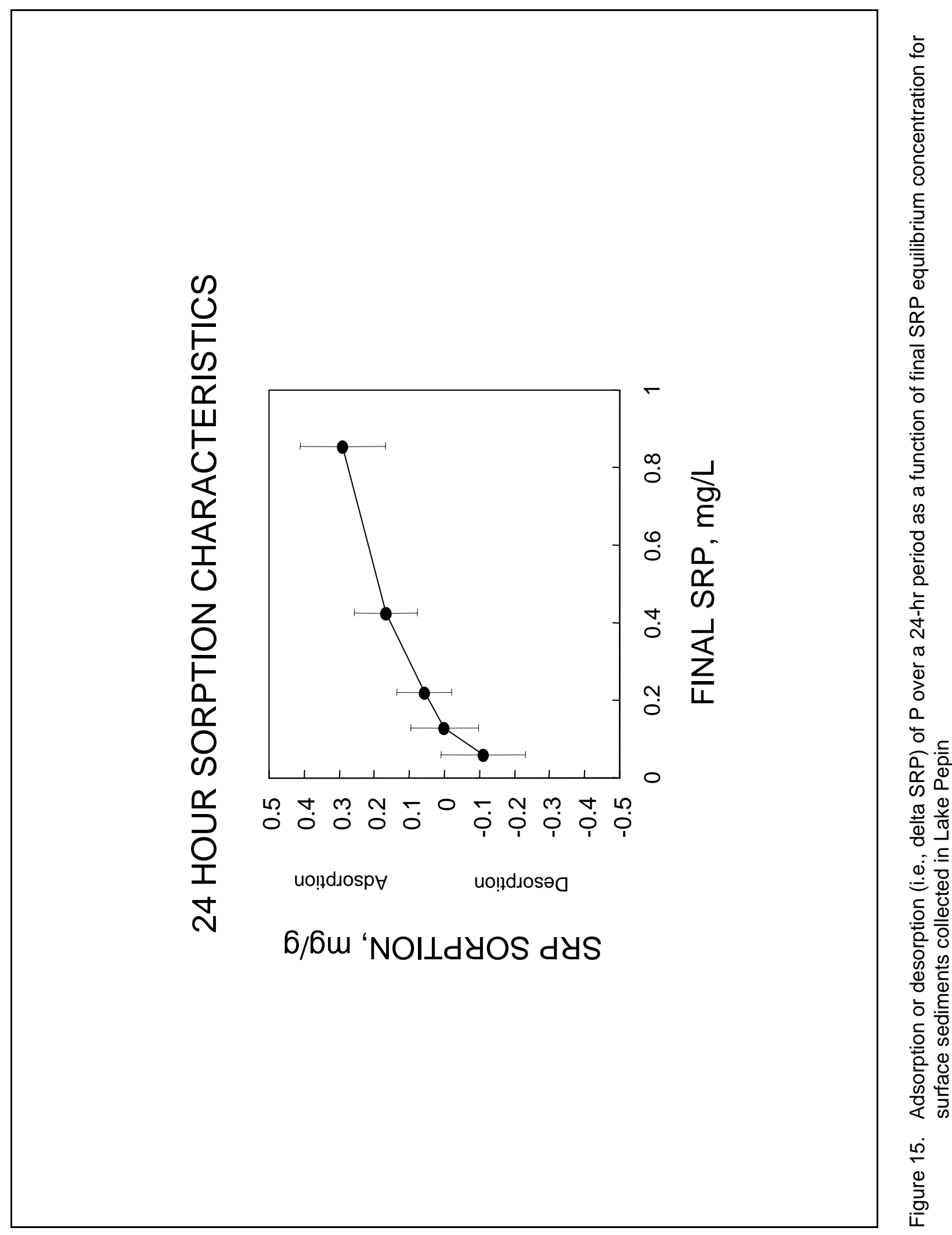




\begin{tabular}{|c|c|c|}
\hline \multicolumn{3}{|c|}{$\begin{array}{l}\text { Table } 3 \\
\text { Mean ( } \pm 1 \text { S.E.) Equilibrium Phosphate (P) Concentration, Native } \\
\text { Adsorbed } P \text { at Equilibrium, and Linear Adsorption Coefficient for } \\
\text { Surface Sediments Collected in Lake Pepin }\end{array}$} \\
\hline $\begin{array}{l}\text { Equilibrium } P \\
\text { Concentration, } \mathrm{mg} / \mathrm{L}\end{array}$ & Native Adsorbed $P, \mathrm{mg} / \mathrm{g}$ & $\begin{array}{l}\text { Linear Adsorption } \\
\text { Coefficient, L/g }\end{array}$ \\
\hline $0.162(0.018)$ & $0.178(0.058)$ & $1.07(0.224)$ \\
\hline
\end{tabular}

\begin{tabular}{|c|c|c|c|c|}
\hline \multicolumn{5}{|c|}{$\begin{array}{l}\text { Table } 4 \\
\text { External Soluble Reactive Phosphorus (SRP) Loading (a), Net SRP Export from Lake } \\
\text { Pepin (i.e., inflow minus outflow) (b), Whole-Lake Estimated Rate of Phosphorus (P) } \\
\text { Release via Diffusion from Profundal Sediments, Based on Laboratory Measurements } \\
\text { and In Situ Variations in Temperature and Dissolved Oxygen (c), and the Rate of P } \\
\text { Release via Desorption from Suspended Sediments Entering Lake Pepin (d) }\end{array}$} \\
\hline (a) Year & $\begin{array}{l}\text { (b) External SRP } \\
\text { Loading, } \mathrm{m} \mathrm{m} \mathrm{m}^{-2} \text { day }^{-1} \\
\end{array}$ & $\begin{array}{l}\text { (c) Net SRP Export, } \\
\mathrm{mg} \mathrm{m}^{-2} \text { day }^{-1}\end{array}$ & $\begin{array}{l}\text { (d) P Release via } \\
\text { Diffusion from Profundal } \\
\text { Sediments, } \mathrm{mg} \mathrm{m}^{-2} \text { day }^{-1} \\
\end{array}$ & $\begin{array}{l}\text { (e) P Release via Desorption } \\
\text { from Suspended Sediments, } \\
\mathrm{mg} \mathrm{m}^{-2} \text { day }^{-1} \\
\end{array}$ \\
\hline 1994 & 66.2 & 20.2 & 6.1 & 3.7 \\
\hline 1995 & 69.0 & 21.3 & 9.3 & 3.6 \\
\hline 1996 & 43.5 & 12.9 & 7.2 & 2.3 \\
\hline Average & 59.6 & 18.1 & 7.5 & 3.2 \\
\hline
\end{tabular}




\section{Discussion}

Loading of total P and SRP from the Minnesota River and the Metro Plant were clearly important sources that dominated the P economy of Lake Pepin. However, an unusual feature of $\mathrm{P}$ dynamics in the lake was the observation of concomitant net total $\mathrm{P}$ retention and net SRP export during summer periods. The occurrence of substantial net export of SRP from the lake during the summer was surprising, given the occurrence of high concentrations of SRP entering the lake. Nevertheless, this net export represented $\sim 25$ percent of the total SRP load to the lake. These contrasting patterns indicated the occurrence of sedimentation of a portion of the external $\mathrm{P}$ load as well as some recycling via diffusive flux from profundal sediments and/or kinetic flux of $\mathrm{P}$ from particulate to soluble phases from suspended sediments entering Lake Pepin.

Rates of internal P loading from profundal sediments under both oxic and anoxic conditions were high in Lake Pepin and fell within ranges of rates measured for sediments collected in a variety of eutrophic lakes (Nürnberg et al. 1986). However, whole-lake estimates of internal $P$ loading from profundal sediments during the summer accounted for only $\sim 50$ percent or less of the net SRP export suggesting that other sources of internally derived soluble $\mathrm{P}$ were also important to the $\mathrm{P}$ budget of the lake. The whole-lake rates were based largely on the occurrence of oxic conditions, as oxygen concentrations greater than $2 \mathrm{mg} \mathrm{L}^{-1}$ were usually observed in the bottom waters of the lake during the summer (James, Barko, and Eakin 1997). Thus, predicted whole-lake rates were relatively low, compared with rates determined under anoxic conditions.

However, the possibility was not examined that temporary anoxia may have developed near the sediment surface in Lake Pepin. If temporary anoxia and accompanying higher rate of $\mathrm{P}$ release were occurring frequently in Lake Pepin, it would have resulted in a greater whole-lake rate of internal $P$ loading from profundal sediments than estimated, thereby accounting for a greater percentage of the net SRP export in the summer.

Another mechanism that could have enhanced the rate of internal P loading from profundal sediments was elevated $\mathrm{pH}$, particularly under oxic conditions. James, Barko, and Eakin (1997) observed that P release from sediments in Lake Pepin was influenced by elevated $\mathrm{pH}$, as rates doubled with an increase in $\mathrm{pH}$ from 8.7 (2.9 $\mathrm{mg} \mathrm{P} \mathrm{m}^{-2}$ day $\left.^{-1}\right)$ to $9.3\left(6.0 \mathrm{mg} \mathrm{P} \mathrm{m}^{-2}\right.$ day $\left.^{-1}\right)$ at $18{ }^{\circ} \mathrm{C}$. Others (Andersen 1975; Lee, Sonzogni, and Spear 1977; Lijklema 1980; Böstrom, 
Jansson, and Forsberg 1982; Böstrom et al. 1988; Drake and Heaney 1987; James and Barko 1991; Jensen and Andersen 1992; James, Barko, and Field 1996) have observed enhanced $\mathrm{P}$ release from sediments at high $\mathrm{pH}$ under oxic conditions.

Although high productivity can drive $\mathrm{pH}$ upwards to values of 10 or greater in aquatic systems, in situ $\mathrm{pH}$ values over 8.9 over a 3-year period in Lake Pepin were not observed (James, Barko, and Eakin 1997), suggesting that $\mathrm{pH}$ may not be as important a factor as elsewhere in regulating the rate of $\mathrm{P}$ release from sediments under oxic conditions. Like oxygen, however, oftentimes dramatic fluctuations in $\mathrm{pH}$ that can potentially occur in aquatic systems over diel time scales were not accounted for (James et al. 1996).

Sediments in Lake Pepin had a relatively high EPC and NAP compared with other studies (Meyer 1979; Mayer and Gloss 1980; studies sited in Floelich 1988; Olila and Reddy 1993), indicating a strong potential for equilibrium and kinetic influences of $\mathrm{P}$ concentrations in the water column under conditions of $\mathrm{P}$ disequilibrium. In particular, it appeared that much of the suspended seston loading, originating primarily from the Minnesota River, was retained in Lake Pepin (James, Barko, and Eakin 1997), compared with upstream pools, indicating the possibility of equilibrium and kinetic reactions between solid and aqueous phases as particles settled in the lake. When converted to a rate of internal P loading in Lake Pepin, estimated $\mathrm{P}$ desorption from suspended seston was very high and equivalent to rates of $P$ release from eutrophic sediments under anoxic conditions. When incorporated into the overall $\mathrm{P}$ budget for Lake Pepin, $\mathrm{P}$ desorption from suspended seston accounted for 25 percent to nearly 40 percent of the measured internal $\mathrm{P}$ load to the lake and was, thus, an important internal flux that is not commonly included in $\mathrm{P}$ budgets of lakes.

Dilution effects by the St. Croix River, located 10 miles upstream of Lake Pepin, were probably a very important mechanism in driving $\mathrm{P}$ disequilibrium as suspended seston was transported into Lake Pepin during the summer. Concentrations of SRP were typically high and near the EPC in regions upstream of the mouth of the St. Croix River (see Figure 12) during the summer, largely because of inputs from the Minnesota River and Metro Plant. St. Croix River inflows, typically very low in SRP, diluted concentrations of SRP substantially below the EPC before flows entered Lake Pepin.

Changes in flow, residence time, and loading of sediment in the UMR may also have a regulating influence on adsorption-desorption dynamics and SRP concentrations in Lake Pepin. During winter, for instance, SRP was near the EPC in Lake Pepin in conjunction with low flows, minimal suspended seston loading, and SRP concentrations that were influenced largely by the Metro Plant. Under these conditions, SRP typically decreased in concentration from the EPC along the longitudinal axis of Lake Pepin. These patterns could be attributed to adsorption of SRP onto sediments and/or uptake by algae. During periods of very high flow (i.e., spring snowmelt and spring storms), discharges from the large watersheds of the Minnesota and Mississippi rivers, coupled with a low residence time in the UMR, became increasingly more important in regulating 
SRP in Lake Pepin, as dilution effects by the St. Croix River diminished because of lesser flows from this system. Deviations from the EPC occurred most frequently in Lake Pepin during the summer months when flows, loadings, and residence times were moderate. Under these conditions, disruption of $\mathrm{P}$ equilibrium via St. Croix inflows, coupled with higher residence times in Lake Pepin, appeared to be important in driving adsorption-desorption processes in the lake.

Sediment resuspended into the water column during the summer via wind activity, heavy barge/boat traffic, and/or benthic fish activity could also be equilibrating with aqueous phases of $\mathrm{P}$ in Lake Pepin. There is indirect evidence that sediment resuspension was very high in this lake, based on comparisons between sedimentation rates measured via sediment traps and via mass balance of suspended seston loading (James and Barko 1995, 1996), suggesting the possibility of internal $\mathrm{P}$ loading via $\mathrm{P}$ equilibrium processes between resuspended sediment and water. Other possible mechanisms that could cause a shift in $\mathrm{P}$ from particulate to soluble phases in Lake Pepin during the summer are biologically mediated transformations because of, for instance, bacterial metabolism, algal decomposition, zebra mussels that have recently colonized the lake, and zooplankton grazing.

Although high loading of $\mathrm{P}$ from inflows upstream of Lake Pepin appears to play an important role in its $\mathrm{P}$ economy, the lake exhibits unusually high export of SRP during the summer that are due to internal $P$ loading processes. Internal $\mathrm{P}$ loading via diffusive fluxes from profundal sediments and kinetic fluxes from suspended-sediment loading account for a substantial proportion of the net SRP flux from Lake Pepin during the summer and need to be considered in $\mathrm{P}$ management strategies for the lake. In particular, the importance to the $\mathrm{P}$ economy of $\mathrm{P}$ adsorption-desorption processes by suspended sediment, a rarely determined flux, has important implications for $\mathrm{P}$ dynamics at locations downstream of Lake Pepin in the UMR. 


\section{References}

Ameel, J. J., Axler, R. P., and Owen, C. J. (1993). "Persulfate digestion for determination of total nitrogen and phosphorus in low nutrient waters," Am. Environ. Lab., 8-10.

Andersen, J. M. (1975). "Influence of $\mathrm{pH}$ on release of phosphorus from lake sediments," Arch. Hydrobiol. 76, 411-419.

American Public Health Association (APHA). (1992). Standard methods for the examination of water and wastewater. 18th ed.

Boström, B., Jansson, M., and Forsberg, C. (1982). "Phosphorus release from lake sediments," Arch. Hydrobiol. Beih. Ergebn. Limnol. 18, 5-59.

Boström, B., Andersen, J. M., Fleischer, S., and Jansson, M. (1988). "Exchange of phosphorus across the sediment-water interface," Hydrobiologia 170, 229-244.

Drake, J. C. D., and Heaney, I. (1987). "Occurrence of phosphorus and its potential remobilization in the littoral sediments of a productive English Lake," Freshwat. Biol. 17, 513-523.

Froelich, P. N. (1988). "Kinetic control of dissolved phosphate in natural rivers and estuaries: A primer on the phosphate buffer mechanism," Limnol.

Oceanogr. 33, 49-668.

James, W. F., and Barko, J. W. (1991). "Littoral-pelagic phosphorus dynamics during nighttime convective circulation," Limnol. Oceanogr. 36, 179-187.

. (1995). "Analysis of nutrient/seston fluxes and phytoplankton dynamics in Lake Pepin (Upper Mississippi River), 1994: First annual report," Report submitted to the Metro Council, St. Paul, MN.

. (1996). "Analysis of nutrient/seston fluxes and phytoplankton dynamics in Lake Pepin (Upper Mississippi River), 1995: Second annual report," Report submitted to the Metro Council, St. Paul, MN. 
James, W. F., Barko, J. W., and Eakin, H. L. (1995). "Internal phosphorus loading in Lake Pepin, Upper Mississippi River," J. Freshwat. Ecol. 10, 269276.

(1997). "Evaluation of sediment characteristics and rates of nutrient release from sediment in Lake Pepin and Spring Lake, Upper Mississippi River," Report submitted to the Metro Council, St. Paul, MN.

James, W. F., Barko, J. W., and Field, S. J. (1996). "Phosphorus mobilization from littoral sediments of an inlet region in Lake Delavan, Wisconsin," Arch. Hydrobiol. 138, 245-257.

Jensen, H. S., and Andersen, F. O. (1992). "Importance of temperature, nitrate, and $\mathrm{pH}$ for phosphorus release from aerobic sediment of four shallow, eutrophic lakes," Limnol. Oceanogr. 37, 577-589.

Lee, G. F., Sonzogni, W., and Spear, R. D. (1977). "Significance of oxic vs. anoxic conditions for Lake Mendota phosphosur release. Interactions between sediments and fresh water. H. Golterman, ed., Junk Publishers, The Hague, 294-306.

Lijklema., L. (1980). "Interaction of orthophosphate with iron (III) and aluminum hydroxides," Environ. Sci. Technol. 14, 537-540.

Lung, W. S., and Larson, C. E. (1995). "Water quality modeling of the upper Mississippi River and Lake Pepin," J. Environ. Eng.

Maurer, W. R., Claflin, T. O., and Rada, R. G. (1995). "Volume loss and mass balance for selected physicochemical constituents in Lake Pepin, Upper Missisippi River," Reg. Rivers 11, 175-184.

Mayer, L. M., and Gloss, S. P. (1980). "Buffering of silica and phosphate in a turbid river," Limnol. Oceanogr. 25, 12-25.

Meyer, J. L. (1979). "The role of sediments and bryophytes in phosphorus dynamics in a headwater stream ecosystem," Limnol. Oceanogr. 24, 365375 .

Minnesota Pollution Control Agency (MPCA). (1993a). "Mississippi River phosphorus study, Section 3: Lake Pepin water quality: 1976 - 1991. Final Report, February, 1993," Minnesota Pollution Control Agency, Water Quality Division, St. Paul, MN.

. (1993b). "Mississippi River phosphorus study, Section 7: Lake Pepin and Mississippi River bathtub modeling. Final Report, March 1993," Minnesota Pollution Control Agency, Water Quality Division, St. Paul, MN.

Nürnberg, G. K. (1984). “The prediction of internal phosphorus loads in lakes with hypolimnetic anoxia," Limnol. Oceanogr. 29, 111-124. 
Nürnberg, G. K., Shaw, M., Dillon, P. J., and McQueen, D. J. (1986). "Internal phosphorus load in an oligotrophic precambrian shield lake with an anoxic hypolimnion," Can. J. Fish. Aquat. Sci. 43, 574-580.

Olila, O. G., and Reddy, K. R. (1993). "Phosphorus sorption characteristics of sediments in shallow eutrophic lakes of Florida," Arch. Hydrobiol. 129, 4565 .

Reddy, K. R., Fisher, M. M., and Ivanoff, D. (1996). "Resuspension and diffusive flux of nitrogen and phosphorus in a hypereutrophic lake," Journal of Environmental Quality 25, 363-371.

Søndergaard, M., Kristensen, P., and Jeppesen, E. (1992). "Phosphorus release from resuspended sediment in the shallow and wind exposed Lake Arres $\varnothing$, Denmark," Hydrobiologia 228, 91-99.

Walker, W. W. (1987). "Empirical methods for predicting eutrophication in impoundments. Report 4. Phase III: Applications manual," Technical Report E-81-9, prepared by William W. Walker, Jr., Environmental Engineer, Concord, MA, for the U.S. Army Engineer Waterways Experiment Station, Vicksburg, MS. 


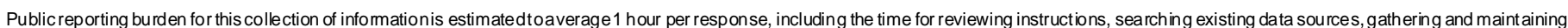

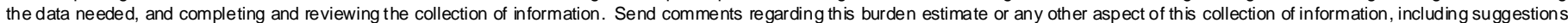

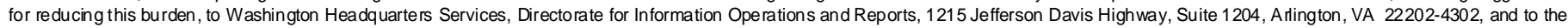
Office of Management and Budget, Paperwork Reduction Project (0704-0188), Washington, DC 20503.
1. AGENCY USE ONLY (Leave blank)

\section{REPORT DATE}
3. REPORT TYPE AND DATES COVERED
September 1999
Final report

\section{TITLE AND SUBTITLE}

Diffusive and Kinetic Fluxes of Phosphorus from Sediments in Relation to

Phosphorus Dynamics in Lake Pepin, Upper Mississippi River

\section{AUTHOR(S)}

William F. James, John W. Barko, Harry L. Eakin

\section{PERFORMING ORGANIZATION NAME(S) AND ADDRESS(ES)}

U.S. Army Engineer Research and Development Center

Waterways Experiment Station

3909 Halls Ferry Road

Vicksburg, MS 39180-6199

9. SPONSORING/MONITORING AGENCY NAME(S) AND ADDRESS(ES)

U.S. Army Corps of Engineers

Washington, DC 20314-1000

5. FUNDING NUMBERS

\section{SUPPLEMENTARY NOTES}

Available from National Technical Information Service, 5285 Port Royal Road, Springfield, VA 22161.

\section{2a. DISTRIBUTIONAVAILABILITY STATEMENT}

Approved for public release; distribution is unlimited.

8. PERFORMING ORGANIZATION REPORT NUMBER

Miscellaneous Paper W-99-1 AGENCY REPORT NUMBER

\section{ABSTRACT (Maximum 200 words)}

Over a 3-year period (1994-96), suspended seston and phosphorus (P) dynamics were examined in the Upper Mississippi River (UMR) and naturally impounded Lake Pepin, with special attention to external and internal P loading processes that may be contributing to deteriorating water quality conditions. The Minnesota River accounted for most of the annual and summer suspended seston ( 81 percent) and total phosphorus ( 44 percent) load, while the Metropolitan Wastewater Treatment Plant (Metro Plant) accounted for $\sim 48$ percent of annual soluble reactive phosphorus (SRP) loading to the UMR. External loading during the summer of sus pended seston, total P, and SRP to Lake Pepin averaged $\sim 30,000 \mathrm{~m}^{-2} \mathrm{day}^{-1}$, and $\sim 60 \mathrm{mg} \mathrm{m}^{-2} \mathrm{day}^{-1}$, respectively. The lake retained a substantial portion of the summer suspended seston load and was also a sink for total P. While total P concentrations generally declined in Lake Pepin from headwaters to outflow, SRP exhibited a trend of increasing concentration from headwaters to outflow with net SRP export during the summer. These contrasting patterns in total $\mathrm{P}$ and SRP indicated the occurrence of internal $\mathrm{P}$ loading and/or transformations in the water column of $\mathrm{P}$ from particulate to soluble phases.

Internal diffusive P flux from profundal sediments, estimated from laboratory incubation systems under different temperature and redox conditions, averaged $\sim 7.5 \mathrm{mg} \mathrm{m}^{-2}$ day $^{-1}$ during the summer under predominately oxic conditions over all years. Although this oxic rate was high relative to other eutrophic lakes, it accounted for $<15$ percent of both the external total P and SRP loads to Lake Pepin. It did, however, account for 30 to 56 percent of the net SRP export from the lake during the summer. Sediments in Lake Pepin also had a high equilibrium P concentration (EPC $=0.162 \mathrm{mg} / \mathrm{L} \pm 0.018 \mathrm{~S} . \mathrm{E}$. $)$ and native adsorbed $\mathrm{P}$ pool (NAP $=0.178 \mathrm{mg} / \mathrm{g} \pm 0.058 \mathrm{~S}$.E.) at equilibrium. During the summer, SRP concentrations of flows entering Lake Pepin were lower than the EPC because of dilution effects by the St. Croix River, located 10 miles upstream

(Continued)

\section{SUBJECT TERMS}

Equilibrium phosphate concentration

External phosphorus loading Internal phosphorus loading
Lake Pepin

Phosphorus

Upper Mississippi River
15. NUMBER OF PAGES 44

16. PRICE CODE

\begin{tabular}{|l|c|c|}
\hline $\begin{array}{l}\text { 17. SECURITY CLASSIFICATION } \\
\text { OF REPORT }\end{array}$ & $\begin{array}{c}\text { 18. SECURITY CLASSIFICATION } \\
\text { OF THIS PAGE } \\
\text { UNCLAS SIFIED }\end{array}$ & $\begin{array}{c}\text { 19. SECURITY CLASSIFICATION } \\
\text { OF ABSTRACT }\end{array}$ \\
\hline
\end{tabular}

NSN 7540-01-280-5500
Standard Form 298 (Rev. 2-89)

Prescribed by ANSI Std. Z39-18 298-102 


\section{3. (Concluded).}

of the lake, indicating a strong potential for $\mathrm{P}$ desorption from suspended seston entering the lake. When converted to a rate of internal $\mathrm{P}$ loading, estimated $\mathrm{P}$ desorption from suspended seston was very high (range $=2.3-3.7 \mathrm{mg} \mathrm{m}^{-2}$ day $^{-1}$ ) and equivalent to rates of $P$ release from eutrophic sediments in aquatic systems under anoxic conditions. When incorporated into the overall P budget for Lake Pepin, P desorption from suspended seston accounted for 25 percent to nearly 40 percent of the measured internal $P$ load (i.e., diffusive plus kinetic) to the lake and was, thus, an important internal flux that is not commonly included in $\mathrm{P}$ budgets of lakes. 